NBER WORKING PAPER SERIES

\title{
CAPITALIZATION OF CHARTER SCHOOLS INTO RESIDENTIAL PROPERTY VALUES
}

\author{
Scott A. Imberman \\ Michael Naretta \\ Margaret O'Rourke \\ Working Paper 20990 \\ http://www.nber.org/papers/w20990 \\ NATIONAL BUREAU OF ECONOMIC RESEARCH \\ 1050 Massachusetts Avenue \\ Cambridge, MA 02138 \\ February 2015
}

The research reported here was supported by the Institute of Education Sciences, U.S. Department of Education, through Grant R305B090011 to Michigan State University. This grant supports MSU's doctoral training program in the economics of education. The opinions expressed are those of the authors and do not represent views of the Institute or the U.S. Department of Education. We are grateful for the support. We would also like to thank Robert Bifulco, Eric Brunner and seminar participants at Michigan State University and the Association for Education Finance and Policy for helpful comments and suggestions. All errors and omissions are our own. The views expressed herein are those of the authors and do not necessarily reflect the views of the National Bureau of Economic Research.

NBER working papers are circulated for discussion and comment purposes. They have not been peerreviewed or been subject to the review by the NBER Board of Directors that accompanies official NBER publications.

(C) 2015 by Scott A. Imberman, Michael Naretta, and Margaret O'Rourke. All rights reserved. Short sections of text, not to exceed two paragraphs, may be quoted without explicit permission provided that full credit, including $(\odot)$ notice, is given to the source. 
Capitalization of Charter Schools into Residential Property Values

Scott A. Imberman, Michael Naretta, and Margaret O’Rourke

NBER Working Paper No. 20990

February 2015

JEL No. H41,I21,I22,R21

\section{ABSTRACT}

While prior research has found clear impacts of schools and school quality on property values, little is known about whether charter schools have similar effects. Using sale price data for residential properties in Los Angeles County from 2008 to 2011 we estimate the neighborhood level impact of charter schools on housing prices. Using an identification strategy that relies on census block fixed-effects and variation in charter penetration over time, we find little evidence that the availability of charter schools affect housing prices on average. However, we do find that when restricting to charter schools located in the same school district as the household, housing prices outside Los Angeles Unified School District fall in response to an increase in nearby charter penetration.

Scott A. Imberman

Michigan State University

486 W. Circle Drive

110 Marshall-Adams Hall

East Lansing, MI 48824-1038

and NBER

imberman@msu.edu

Michael Naretta

Michigan State University

486 W Circle Dr

110 Marshall-Adams Hall

East Lansing, MI 48824-1038

narettam@msu.edu
Margaret O'Rourke

Michigan State University

486 W Circle Dr.

110 Marshall-Adams Hall

East Lansing, MI 48824-1038

orourk49@msu.edu 


\section{Introduction}

The charter school movement began about twenty years ago and was driven by the belief that privately run and publicly financed schools could be superior to traditional public schools. Proponents argue that charters can adapt more smoothly in times of financial hardship than traditional schools (e.g. by reducing non-unionized labor force or changing administrative policies). They also argue that charters are leaders in methodological innovations in education. On the other hand, opponents argue that charters are able to restrict admission to make them look better than they are and that they divert necessary resources from public schools. While existing research has generally shown charters to be at least as effective as, and in many cases better than, public schools (e.g. Angrist, Pathak and Walters, 2013; Angrist et al., 2012; Abdulkadiroglu et al., 2011; Dobbie and Fryer, 2011; Imberman, 2011b; Hoxby and Murarka, 2009; Bifulco and Ladd, 2006; Sass, 2006; Bettinger, 2005) the impacts of these schools on the wider economy is not well known. In this paper we attempt to establish the extent to which charter schools impact local tax bases by examining how charter penetration rates in a community are capitalized into surrounding home prices using data in Los Angeles County (LA County), California. To our knowledge, this is the first analysis examining whether housing markets are responsive to charter availability, which is important given the increasing prevalence of charter schools across the country. Indeed, California has seen significant growth in the number of charter schools since they were authorized in 1992; the overall number of charters has increased from 299 in 2000 to 912 in 2010, with 242 of those in LA County alone. This is the highest number of charter schools in any county in the U.S. ${ }^{2}$

While there is also a substantial literature relating housing values and school characteristics (e.g. Imberman and Lovenheim, 2013; Gibbons, Machin and Silva, 2011; Bayer,

\footnotetext{
${ }^{2}$ California Charter Schools Association, accessed via www.calcharters.org.
} 
Ferreira and McMillan, 2007; Kane, Riegg and Staiger, 2006; Figlio and Lucas, 2004; Gibbons and Machin, 2003; Black, 1999), only Buerger (2014) in an unpublished working paper specifically considers home owners' valuation of charter schools. To estimate the impact of charters on housing prices, we use data on single-family home sales from 2008-2011, obtained from Los Angeles County Assessor's Office. We estimate the impacts of both the number of charters and the share of public enrollment in charters within various distances of a property up to two miles. To account for endogenous charter locations and changes in the geographic distribution of sales we include census block fixed effects along with a set of housing and school characteristics to account for the non-random location of charter schools. Month-by-year fixedeffects account for any general changes to the education and housing markets over time in LA County. ${ }^{3}$ Thus, our identification comes from houses sold in the same census block at different times as charters open, close, expand and shrink. As a result, we note that our study does not identify how existing charter enrollment affects housing prices but rather how contemporaneous changes in charter enrollment and the number of charters affect housing prices in localized areas, specifically within census blocks.

Overall, our results suggest that neither increases in the number of charter schools nor the expansion in charter enrollment relative to public school enrollment - our proxy for the availability of charter school slots to local residents - are capitalized into housing prices on average. This holds both for Los Angeles Unified School District (LAUSD) and other parts of Los Angeles County. It also holds for both startup charters - new schools that begin as charters and conversion charters - public schools that convert to charter status, though we caution that very few schools convert during our sample period. Further, we find no evidence that

\footnotetext{
${ }^{3}$ We acknowledge, nonetheless, that since we do not have neighborhood controls that vary over time, our model does not account for changes in neighborhoods independent of changes in local schools that may affect charter penetration. We discuss this issue in more detail in the empirical strategy section below.
} 
capitalization varies with income level, minority population, or achievement levels of the local public elementary school.

However, we do find that when we count charters located only within the household's school district's boundaries and exclude LAUSD there is a significant negative effect of additional nearby charter schools on housing prices. This restriction is reasonable as students who reside within the charter's authorizing school district (which is almost always the district they are located in) have admissions priority, thus generating a link between these schooling options and local district boundaries. A potential explanation for this finding is that opening a nearby charter school reduces the value of a local community school, thus weakening the link between the availability of local schooling as a public good and house prices.

\section{Charter Schools Background}

Charter schools are public schools that are tuition-free and managed by an independent operator. Typically they are open to any student wishing to attend, regardless of where they live, though some schools give preference to students who reside nearby. Many schools require an application, and those that are in high demand will often have a waitlist. Charters are typically governed by parents, teachers, members of the local community, or a private company and are reviewed for renewal every few years by an authorizer, usually the state or a local school district. In California, charters are funded through a mix of block grants and a state-based funding formula that provides funding at the same per-pupil rate to all charters of a given grade level across the state. ${ }^{4}$ There is substantial heterogeneity across schools in the way they are managed,

\footnotetext{
4 “Charter Schools FAQ Section 3," California Department of Education, accessed http://www.cde.ca.gov/sp/cs/re/qandasec3mar04.asp.
} 
their goals, their targeted student population, and level of autonomy from the local school system.

An important distinction to recognize among charter schools is that they are either brand new schools - startup charters - or were previously a traditional public school that switched to a charter model - conversion charter. According to the California Charter Schools Association, there are many reasons why traditional schools decide to convert to charter status, but above all is the appeal of increased flexibility and autonomy. Conversion charters must satisfy the same legal requirements and processes as startup charter schools. This involves submitting a charter petition establishing features such as the school's goals, finances, and governance plan, as well as obtaining signatures of at least fifty percent of the permanent teachers currently employed at the school. ${ }^{5}$ However, California law does require that conversions give priority to students in the school's district and many districts, including Los Angeles Unified, give priority to students in a local catchment area. Typically startup charters do not have catchment areas, but if they are over-subscribed they are also required to give priority to students who reside in the authorizing school district and may choose to give priority to those in the local school zone if the neighborhood school has high rates of economic disadvantage.

As of the 2010-2011 school year, conversion charters represented 16 percent of California's charter schools, enrolling about 25 percent of all charter school students. ${ }^{6}$ Charter school facilities vary with type of charter, with some building brand new structures, renting available spaces in churches, community centers, or commercial buildings, or occupying a

\footnotetext{
5 "School Conversion," California Charter Schools Association, accessed via www.calcharters.org/starting/conversion/.

6 "Conversion Charter Schools: A Closer Look," California Charter Schools Association, accessed via www.calcharters.org/2012/04/conversion-charter-schools-a-closer-look.html.
} 
previously traditionally run public school campus. ${ }^{7}$ When a school converts to charter status, it usually remains in the same building and retains teachers, staff, and students. In contrast, startup charters need to recruit a student body because parents have the option to enroll their child in the charter or in the assigned public school.

Another important distinction between types of charter schools that has drawn interest recently is the role of larger charter management organizations (CMOs). CMOs are non-profits that operate multiple charter schools and charters within an organization are able to pool management and resources in order to gain economies of scale, a benefit often shared by schools within a traditional public school district. Evidence of the impacts of these types of charters on student outcomes suggest that effectiveness varies substantially across CMOs and students (Furgeson, et al., 2012; Angrist, et al., 2012). Another heterogeneous distinction between charter schools is whether a charter has a waiting list. Recent work using oversubscription lotteries has indicated that waitlist charters perform better than local public schools but are unable to assess the impacts of non-waitlist charters (Angrist, Pathak and Walters, 2013; Angrist et al., 2012; Abdulkadiroglu et al., 2011; Dobbie and Fryer, 2011; Hoxby and Murarka, 2009). Unfortunately, while it would be interesting to see whether housing prices respond differently to these two ways charters vary, we do not have data on whether charters are operated by CMOs or have waitlists.

\section{Theory of Charter Impacts on Housing Prices}

The theory behind the relationship between housing prices and local school quality predicts that, due to the close link between residential location and the school attended via attendance zones, higher quality schooling will generally lead to an increase in housing prices, though the extent of this increase depends on a number of factors (Black and Machin, 2011;

\footnotetext{
${ }^{7}$ California Charter Schools Association, accessed via www.calcharters.org.
} 
Rosen, 1974). This relationship has been well established through empirical analyses (Gibbons, Machin and Silva, 2013; Bayer, Ferreira and McMillan, 2007; Kane, Reigg and Staiger, 2006; Figlio and Lucas, 2004; Downes and Zabel, 2002; Black, 1999). However, since charter schools do not typically have attendance zones and typically students may attend a charter regardless of their location of residence, the theoretical link between charter schools and housing prices is ambiuous.

Despite a less obvious link between charter schools and housing prices, economic theory suggests homeowners may respond to charters in a neighborhood for a few reasons. First, charters provide an option value. Even if a child does not attend a charter school, the availability of charters nearby may make a location more attractive for parents. Since charters rarely offer busing, travel distance is especially important if transport costs are expensive as is the case in Los Angeles County where there is limited public transportation, heavy traffic congestion and high gas prices.

Second, charters may have an indirect effect on housing prices if they affect the performance of local public schools. Evidence on how charters affect local public schools is mixed. While Booker, Gilpatric, Gronberg and Jansen (2008), Bifulco and Ladd (2006), and Sass (2006) find positive effects of charters on nearby public schools, Imberman (2011a) finds negative effects. Thus it is unclear how this mechanism might influence housing prices.

Third, the public may value the direct infrastructure and community improvements charters sometimes provide. Indeed, Cellini, Ferreira and Rothstein (2010) show that housing prices respond to non-charter public school facility investments. While many charters rent or use donated space, some build their own facilities or convert abandoned properties for use as schools. Even those that rent will often fill up vacant properties in locations like strip malls 
(Imberman, 2011a). Thus the additional economic activity generated by the charters may influence local housing prices.

Another theory is that charter schools may serve to break the connection between local public schools and housing prices. In so doing we might expect additional charters (and more school choice options more broadly) to lead to increased housing prices where existing schools are low performing as these locations would have artificially low housing values due to the poor school quality. Alternatively, in high performing areas, additional charters may actually reduce housing prices as the availability of nearby charters weakens a key benefit of being zoned to a high-performing school if, through attending charters, high school quality becomes available to households outside the attendance zone (Nechyba, 2003). Another possibility, however, is that by severing this link, the availability of having a public school option at all, irrespective of school quality, is less valuable. The public good of a local school provides less utility and thus, without a commensurate reduction in property taxes, lowers the value of living near that school.

The theories outlined above indicate that it is unclear how charter schools may affect housing prices as some economic effects may be positive and some may be negative. As such, understanding the overall effect on local property markets is necessarily an empirical question. We should also note that while it may be tempting to interpret housing price responses as measures of how much people value charters, the complexity of the underlying processes makes it difficult to do this. In fact the theories described above of how charter schools may sever the link between local public schools and property values highlight that the effects could be showing something entirely different than valuation. From the standpoint of education policy a particularly important implication is that changes in property values can impact the fiscal situation of school districts. For example, due to the movement of students to charters, many 
districts lose revenue when charters open. However, if district revenue is closely linked to local property taxes then charter schools can generate further revenue losses (gains) if they induce reductions (increases) in property values. Such reasoning also applies to financing for other local governments that rely heavily on property taxes. Hence, the response of property markets to additional nearby charters provides important information for school districts and local governments for preparing revenue estimates and budgeting.

\section{Previous Literature}

Most of the existing literature on charter schools focuses on the effect of charters on student achievement. Early research that relies on panel data methods have found mixed results, with some researchers finding insignificant or significant negative impacts of attending a charter school on student test scores (Imberman, 2011b; Hanushek, Kain, Rivkin and Branch, 2007; Bifulco and Ladd, 2006; Sass 2006; Zimmer and Buddin, 2006), and others finding positive impacts (Booker, Gilpatric, Gronberg and Jansen, 2008; Hoxby and Rockoff, 2004). More recent research employing random lotteries (Angrist, Pathak and Walters, 2013; Angrist et al., 2012; Abdulkadiroglu et al., 2011; Dobbie and Fryer, 2011; Hoxby and Murarka, 2009) and natural experiments (Abulkadiroglu et al., 2014) have found large positive effects. Some research has also recognized the distinction between conversion and startup charters and suggests there is a differential impact on performance across the two types (Sass, 2006; Buddin and Zimmer, 2005; Zimmer and Buddin, 2009).

There are two studies in particular that are similar to ours. First, Chakrabarti and Roy (2010) try to use the impact of charter schools on enrollment in private schools as a proxy for how much parents prefer charters to other schooling options. They find modest declines in 
private school enrollment when charters locate nearby. Second, in an unpublished working paper Buerger (2014) looks at differences in housing prices across school districts in New York due to charter penetration and finds positive effects. His identification relies on differences in charter penetration across school districts and census-tract fixed effects.

Nonetheless, our paper is distinct from Buerger (2014) in a few key ways. First, the focus on differences across districts, while useful in areas with many school districts, is less relevant to areas like Los Angeles that are dominated by a large central core district. Indeed, most charter schools tend to locate in urban core areas dominated by large urban districts. Thus, our analysis allows for identification of charter impacts within these urbanized areas. Second, Buerger looks at the impacts on housing prices from the entry of the first charter school into the district. In our analysis, we look at capitalization of marginal changes in charter penetration using multiple charter penetration measures. Third, our inclusion of census-block fixed-effects instead of the geographically larger census-tract fixed effects allows us to account for more potential sources of time-invariant unobserved characteristics.

A separate branch of literature focuses on the relationship between housing prices and school characteristics. There is ample evidence from previous work that housing prices are responsive to test score differences across schools. ${ }^{9}$ Both Black (1999) and Bayer, Ferreira and McMillan (2007) estimate regression discontinuity models across school zone boundaries to identify how school-average test scores are capitalized into housing prices. Figlio and Lucas (2004) examine the effect of the release of "school report card" data in Florida on property values. These report cards rated schools from A to F based on average performance on statewide exams. All three studies find sizable, positive impacts of higher school test scores on home values, suggesting that parents place significant value on this school quality measure. Gibbons,

\footnotetext{
${ }^{9}$ For a comprehensive review see Black and Machin (2011).
} 
Machin and Silva (2013) find similar results in England using boundary discontinuities using test score gains. On the other hand, Imberman and Lovenheim (2013) find little impact of the release of teacher and school value-added information on housing prices in Los Angeles.

Several studies have considered the effects of other school characteristics such as student demographics, per-pupil spending, and pupil-teacher ratio, on housing prices. In the footsteps of Oates' (1969) seminal paper, which uses per pupil spending and pupil-teacher ratio as measures of school quality, much of this research has found positive relationships between similar measures and housing prices (Bradbury, Mayer and Case, 2001; Bogart and Cromwell, 1997; Weimer and Wolkoff, 2001). Clapp, Nanda and Ross (2008), using panel data from Connecticut, find that an increase in the percentage of Hispanic students has a negative effect on housing prices. Using data from Chicago, Downes and Zabel (2002) find that households do not capitalize per-pupil expenditures.

Bogart and Cromwell (2000) exploit school redistricting in Ohio and find that disruption of neighborhood schools - in terms of student demographics, changes in transportation services, and geographic location within the neighborhood - reduces house values by nearly 10 percent. Reback (2005) analyzes the effect of adoption of a public school choice program in Minnesota to estimate the capitalization effects related to changes in school district revenues, as districts' state revenues depend on enrollment. He finds that a one percentage point increase in outgoing transfer rates is associated with an increase in house prices of about 1.7 percent.

Our analysis builds off the approaches of these studies, by estimating the impact of charter schools on local housing prices while carefully accounting for selection of charters into neighborhoods. In particular, our baseline specification includes census block fixed effects to 
account for unobserved heterogeneity across local neighborhoods in the propensity for charters to open or close nearby.

V. Data

Our home price data come from the Los Angeles County Assessor's Office (LACAO). The data contain the most recent sale price of every home in Los Angeles County as of October 2011. In addition to Los Angeles Unified School District (LAUSD), the second largest district in the country, the data encompasses 75 other school districts. Since our data is based on most recent sales, to avoid endogenous selection into the sample and small sample sizes in early years, we restrict our data to include only residential sales that occurred between September 1, 2008 and September 30, 2011. From LACAO, we also obtained parcel-specific property maps, which we overlay with school zone maps from 2002, which is the most recent year such data is available for the whole county. ${ }^{10}$ The data also include home and property characteristics, such as the number of bedrooms, the number of bathrooms, units on the property, square footage, and the year the structure was built.

We drop all properties with sale prices above $\$ 1.5$ million in order to avoid results being driven by home price outliers. Further, about 25 percent of the residential properties in the dataset do not have a sale price listed. Usually, these are property transfers between relatives or inheritances. Hence, we limit our sample to those sales that have "document reason codes" of "A," which denotes that it is a "good transfer" of property. We also drop all properties with more than either eight bedrooms or eight bathrooms.

\footnotetext{
${ }^{10}$ The 2002 LA County maps come from the Los Angeles County eGIS portal at http://egis3.lacounty.gov/dataportal/. The maps were created using a variety of sources and thus may not match precisely to actual school zones.
} 
The charter school data is from the California Department of Education. We rely on two measures of charter school penetration: the counts of the number of charter schools within a specified distance from a home and the percentage of total enrollment in the public sector attributable to charter schools within a specified distance from a home. For the former measure, we calculate the distance between each charter and the home, and count the number of charters falling within a specified distance. For the latter measure, we use enrollment figures for all public schools in Los Angeles County from the Common Core of Data, managed by the Institute of Education Sciences at the U.S. Department of Education. An explanation for why we choose these variables and our specified distances is provided in the empirical strategy section below.

We combine these data with school-by-academic year data on Academic Performance Index (API) scores, API rank, school average racial composition, percent on free and reduced price lunch, percent disabled, percent gifted and talented, average parental education levels and enrollment. The API score is California's summary index of school test score performance. These covariates, which are available through the California Department of Education, control for the differences in charter school penetration that are correlated with underlying demographic trends in each school.

Our main analytic sample consists of 158,211 house sales occurring from September, 2008 through September, 2011. Of these, 65,170 are sales of homes zoned to an elementary school in LAUSD and 93,041 are sales of homes zoned to an elementary school in another school district in LA County. Table 1 provides information on the types of charter and public schools that operate in LA County over our sample period. Panel A provides schools by grade level. Charters are more common for middle and high schools but still account for a substantial portion of elementary schools at 9 percent. Conversion charters in particular are common for 
elementary schools but not middle and high schools. Panel B shows that over the time period of our study, the percent of schools that are charters grows from 7.7 percent in 2008 to 11.7 percent in 2011. Table 2 and 3 provide sample means and standard deviations at the property level for several of the variables we include in our regressions. In Table 2 we see that properties in Los Angeles County have an average sale price of $\$ 383,546$ and tend to be of modest size, averaging around 3 bedrooms, 2 bathrooms and 1600 square feet. We also have a ranking of the quality of the structures on the property which will be useful for conducting validity tests. The property is given a rating on a scale of 1 to 12.5 by LACAO assessors, where a rating of 12.5 is the highest assessed quality. Not surprisingly, the average quality of a property in LA County is close to the midway point on this scale at 6.45 . For charter penetration, the number of charters in each distance ring increases as we go further out, primarily due to the larger amount of land area in larger distance rings. When we look at charters as a percentage of total public school enrollments, the rates are relatively constant across distance rings at 5 - 6 percent.

We note that our data covers some periods of abnormal rigidity in the Los Angeles housing market due to the housing collapse of 2008 and the Great Recession. Figure 1 shows the Case-Shiller House Price Index for the Greater Los Angeles area from 2008 through 2011. ${ }^{11}$ Even though housing prices in Los Angeles fell dramatically until May 2009, afterwards they had begun to rebound, increasing by 11 percent through July 2010. The prices fell slightly thereafter until the end of our data in September 2011. Thus, the housing market had been in recovery for most of our sample period. Even so, we may be worried that market rigidities would continue to limit capitalization. To address this we provide results in the online appendix that

\footnotetext{
${ }^{11}$ Acquired from http://us.spindices.com/indices/real-estate/sp-case-shiller-ca-los-angeles-home-price-index.
} 
vary by year of sale and show that our estimates are similar to baseline in later years of the sample when the market had more fully recovered. ${ }^{12}$

In panel A of Table 3 we provide information on the characteristics for the elementary, middle, and high schools to which each property is zoned. Panel B provides a comparison with charters at each grade level within 1 mile of the property. For elementary and middle schools, the characteristics of charters are pretty similar to those of the zoned school in terms of enrollment, API score and demographics. For high schools, however, there are some differences. Charter high schools tend to be substantially smaller (1,140 students versus 2,002$)$ but lower performing as measured by API score. Zoned and charter high schools are demographically similar, though high school charters tend to have fewer gifted students.

\section{Empirical Strategy}

Our identification strategy relies on variation across households and over time within a census block in the number of charters within various distance radii. To achieve this, in addition to controls for characteristics of the local elementary school and property characteristics, we include census block fixed-effects along with month-of-sale fixed-effects. Including census block fixed-effects allows us to compare the sale prices of properties that are geographically very close by; the mean land area for census blocks in LA County is 108,322 square feet with a median of 19,283 square feet. While it may be preferable to use repeated sales on the same property, this is not possible with our data as we only have sale price information for the most recent sale. Even if we did have repeated sales, given the short time frame, restricting to those

\footnotetext{
${ }^{12}$ The appendix can be found at http://www.msu.edu/ imberman/appendix imberman_naretta_orouke 2015.pdf.
} 
types of households would create a selected sample as a disproportionate number of those properties may be distressed, in fast changing neighborhoods, or houses that are often "flipped."

We believe that multiple sales within census blocks provide a reasonably small enough geographic area to closely mimic repeated sales for specific properties while avoiding the potential selection issues generated by using repeated sales. For example, in our final estimation sample the median census block in LA County has three sales during the study period with a mean of 3.9. Figure 2 provides a histogram of the distribution of sales within census blocks, conditional on having any sales, over the study period. While our econometric strategy identifies the effect of charter penetration only from blocks with more than one sale, a substantial number of census blocks provide this identification. There are 29,512 blocks with at least two sales and of those, 14,494 blocks have at least four sales and 7,387 blocks have at least six sales. Further, of all blocks with at least one sale, 73 percent have multiple sales, providing wide geographic variation in blocks that contribute to identification. Finally, we conduct an ANOVA analysis of property characteristics to assess the within and between census block variance. In our estimation sample only 39 percent of the variance in house size and 20 percent of the variance in housing quality is within census block, along with less than half of the variation in bedrooms and bathrooms. ${ }^{13}$ These results suggest that different houses within a block have largely similar characteristics.

By including census block fixed effects, our identification strategy assumes that there are no changes in neighborhood conditions over time that are correlated both with housing prices and charter penetration. Of course, housing prices are increasing in general in Los Angeles during our analysis period as is the number of charter schools. Hence, to account for general

\footnotetext{
${ }^{13}$ An ANOVA using the residuals from regressions of the characteristics on month-by-year indicators provides similar results.
} 
changes in house prices related to overall market conditions, we include year-by-month indicators in all of our regression models.

Even with census-block fixed effect and year-by-month fixed effects, it is possible there are factors changing locally that could bias our estimates. Of primary concern is the possibility that charters select into neighborhoods where the local public school is under-performing and the poor quality of the school is reflected in lower housing prices. Ideally, we would be able to at least control for changes in neighborhood characteristics as we do for school characteristics and housing supply. Unfortunately, the data available to us for this is very limited. To our knowledge, only the American Communities Survey (ACS) provides neighborhood data at a small enough geographic level (e.g. census tract) to be relevant for this analysis. However, the ACS only provides five-year estimates at the census tract level as estimates based on smaller periods of time are too imprecise. As a result, the ACS data does not provide temporal variation in neighborhood characteristics over our three-year time period and any data on neighborhood characteristics would be absorbed by the census-block fixed-effects. Thus, we assume that selection of charter location is unrelated to time-varying neighborhood characteristics that are themselves not captured in our housing and school characteristics controls. While we cannot test this assumption directly, we do attempt to address it indirectly by testing whether our observable measures of housing characteristics change when more charters move in and by testing whether charter penetration can be explained by prior changes in house prices. If time varying neighborhood characteristics are correlated with prior house prices and the types of houses put on the market then we should expect to see some impact on these observables, and indeed we do not find evidence for this. Nonetheless, while we do not have temporal variation in neighborhood variables, we do have such variation for local elementary school characteristics. Thus in Table 
A1 of the online appendix, we look at how charter entry relates to public school characteristics when we condition on school fixed- Without school fixed-effects the estimates show that charters tend to locate in the zones of elementary schools with fewer minorities, more gifted students, more English language learners and more disabled students. When school fixed-effects are added some characteristics are statistically significant, but importantly they are all economically small. The largest statistically significant coefficient is on percent of black residents in the public school zone, but this coefficient is still rather small. For a one charter increase in the school zone, there would need to be an increase in percent black by of 84 percentage points. Given this pattern and the general shift in the coefficients towards zero as the school fixed-effects are added, these results suggest that lower levels of geographic fixed-effects, specifically census-block effects, should reduce these correlations further to the point where they are negligible.

Another difficulty in this analysis is deciding how to measure charter penetration. There are two key factors here. First, there is the question as to whether the important factor is the existence of a charter school as a whole or the relative size of a charter school. Arguably, while the former is the most visible aspect of the school to the wider public (people in the neighborhood know that a school exists but may be uncertain as to how large it is), the latter is a potentially better indicator of the supply constraints on a family that wishes to send a child to the charter. The second issue is that it is unclear how far from the charter a household must be before we can be confident that the household should not care about the charter's existence. To deal with both of these issues we follow the prior literature on the effects of charter schools on public schools (Imberman, 2011a, Booker et al., 2008; Bifulco and Ladd, 2006; Sass, 2006). The analyses in these studies estimate the effects of charter schools on traditional public schools 
within concentric rings of various distances. Since it is not obvious whether what matters is relative enrollment in charters or the number of charters they estimate the effects of both charter counts and enrollment in the charters as a share of total enrollment.

We use measures of charter penetration equal to (a) the number of charters and (b) the share of all public school enrollments in charters in concentric rings between 0 and 0.5 miles, 0.5 and 1 miles, 1 and 1.5 miles and 1.5 and 2 miles from a property. We focus our attention on charters within relatively short distances of properties due to the urbanicity and size of school zones in LA County. The mean elementary school zone in LA County has an area of 3.2 square miles. With this area, if school zones were circular, the radius of the average zone would be 1.0 miles. The median school zone has an area of 0.8 square miles translating into a radius of 0.5 miles. Hence, given the size of school zones in LA County, these are reasonable distances within which to measure the effect of charters. Indeed, in a large Southwestern city that is less densely populated than Los Angeles, Imberman (2011a) shows that charters only impact enrollment of public schools within 2 miles of the charter. Further, in an analysis of charter applicants in Boston, Walters (2014) finds that 40 percent of applicants apply to the closest charter school while a further 22 percent apply to the second closest. While we do not have data on who actually applies to or attends charters, we note that in LA County the median property is 1.35 miles from the nearest charter while the second closest charter 2.18 miles away. Since these measures include all properties, it is likely that the average distances for charter attendees are substantially smaller. Based on these factors, we believe that 2 miles is a reasonable maximum distance, though we also check distances between 2 and 5 miles in the online appendix.

Our baseline model estimates the impact of charter penetration on the log of the sales price of property $i$ in census block $s$ at time $t$ as 
(1) $\operatorname{Ln}\left(\right.$ SalePrice $\left._{\text {ist }}\right)=\alpha+$ Charter $_{i t} \boldsymbol{\beta}+\mathbf{X}_{\mathbf{i t}} \boldsymbol{\Gamma}+\mathbf{H}_{\mathbf{i}} \boldsymbol{\Phi}+\lambda_{\mathrm{t}}+\gamma_{\mathrm{s}}+\varepsilon_{\text {it }}$

where Charter is a vector of charter penetration variables calculated as the number of charters or the share of public school enrollment in charters between 0 and 0.5 miles, 0.5 and 1 mile, 1 and 1.5 miles, and 1.5 and 2 miles from the property. The $\boldsymbol{\beta}$ coefficients can be interpreted as jointly identifying a house price gradient that captures the differential valuation of charter penetration by homeowners over distance. $\mathbf{X}$ is a vector of school-by-year observables, where the school is the elementary school to which the property is zoned. $\mathbf{H}$ is a vector of house-specific characteristics, such as the number of bedrooms, the number of bathrooms, age, quality and square footage. The model also includes month-by-year fixed effects $\left(\lambda_{t}\right)$ to control for common time trends and census block fixed effects $\left(\gamma_{\mathrm{s}}\right)$ to control for time-invariant neighborhood quality and quality of the locally zoned school. ${ }^{15}$ We cluster standard errors at the school zone level to account for correlation between prices of properties in the same census block. An adjustment to this model also restricts to charter schools within school-district boundaries. This is relevant since, as previously mentioned, California requires oversubscribed charters to give admissions priority to within-district students.

We expand the baseline model to account for heterogeneous effects on housing price by disaggregating our charter penetration variables by type of charter: conversion or startup. In this model, the charter penetration vector is split into two:

$$
\begin{aligned}
& \text { (2) } \operatorname{Ln}\left(\mathrm{P}_{\mathrm{ist}}\right)=\alpha+\text { StartupCharter }{ }_{i t} \boldsymbol{\beta}_{1}+\text { ConversionCharter }_{i t} \beta_{2}+ \\
& \mathbf{X}_{\mathbf{i t}} \boldsymbol{\Gamma}+\mathbf{H}_{\mathbf{i}} \boldsymbol{\Phi}+\lambda_{\mathrm{t}}+\gamma_{\mathrm{s}}+\varepsilon_{\mathrm{it}}
\end{aligned}
$$

\footnotetext{
${ }^{15}$ The baseline model excludes school-zone fixed effects since most census blocks do not straddle school zones. Nonetheless, inclusion of school-zone fixed effects has a negligible impact on the results.
} 
In this set-up, the $\boldsymbol{\beta}_{\mathbf{1}}$ coefficients will provide a gradient for startup charters and the $\boldsymbol{\beta}_{\mathbf{2}}$ coefficients will provide a gradient for conversion charters. We include the same controls as in equation (1). As mentioned above, we would expect to find differing valuation of these two types of charters if homeowners place different weights on the inputs of each type; conversion charters often remain in the same building, with the same student body and staff, and adopting new operating styles while startup charters are often in rental spaces, tend to be smaller than conversions and traditional public schools, and need to recruit students and staff in addition to operating under a new management style. ${ }^{16}$

VII. Results

Effect of charter penetration on housing prices.

Table 4 provides the baseline results of our analysis using variations of equation (1) and the sample of homes sold across all of LA County. The table includes two panels, one for each charter measure, overall numbers of charters and percentage of total enrollment attributed to charters. Each specification in the table includes month-by-year time dummies, housing controls - square footage, number of bedrooms, number of bathrooms, and quality - and controls for the locally zoned elementary school - enrollment, API score, school demographics, percentage disabled, gifted, free or reduced price lunch eligible, and English language learners. All standard errors are clustered at the school-zone level, where the school is the elementary school to which a property was zoned in 2002 .

\footnotetext{
${ }^{16}$ The fact that conversions usually maintain the same attendance zone after converting suggests the potential for using a difference-in-differences approach to assessing the impacts of these schools on housing prices. Unfortunately, only five schools in LA County convert to charter status during our study period making the estimates from this type of analysis too imprecise.
} 
In columns (i) and (iv) of Table 4, we regress the log of the house price on charter counts and the share of public school enrollment in charters within half mile diameter rings, respectively, without geographic fixed effects. The estimates suggest that there is a positive relationship that strengthens as the distance from the property increases. However, in columns (ii) and (v), we include elementary school-zone fixed effects to account for characteristics of the locally zoned school. In these models the patterns differ depending on how we measure charter penetration. When using charter counts, the results indicate that charters negatively impact housing prices, becoming more negative the closer charters are to the property. The coefficient on the zero to half mile radius charter measure indicates that an additional charter is associated with a statistically significant $3.5 \log$ point decrease in the sale price. When using enrollment share, however, only $1-1.5$ miles is significant.

However, we may still be concerned that there are endogenous differences within school zones, but across neighborhoods, that affect both housing prices and charter penetration. Thus in columns (iii) and (vi) we provide our preferred estimates that replace school-zone fixed effects with census-block fixed-effects. In this model, estimates are all statistically insignificant and small. The largest estimate in column (iii) suggests, when taken at face value, that an additional charter school increases housing prices between 1 and 1.5 miles away by 0.2 percent, with smaller values for other distances. For the enrollment share measure, all of the values are negative, insignificant, and economically small with a 10 percentage point $(\mathrm{pp})$ increase in charter share reducing housing prices by less than 0.2 percent at all distance levels. To provide additional context, if we focus on charter penetration within 0.5 miles of the property, the $95 \%$ confidence interval for the impact of an additional charter is $[-2 \%, 1 \%]$ while for a $10 \mathrm{pp}$ increase in charter enrollment share it is $[0.4 \%,-0.4 \%]$. 
One potentially important issue in interpreting the estimated effect of charter penetration is that as the distance increases, the area in which the charter could locate increases. This is not a substantial concern when focusing on share of enrollment, but it does indicate that there may be more variation in the number of charters in farther rings making comparing the estimated effects of charter penetration at different distances difficult. To address this we also provide estimates using charter penetration within the full 2 mile radius around the property in Panel B. The results are similar to those in Panel A and show no impact of charters on housing prices when we include census block fixed-effects. It is also interesting to note that the standard errors decrease when we add census block (or school) fixed-effects. This is another indicator that there is substantial identifying power within blocks and that including between-block variation adds uninformative noise to the analysis.

Table 5 provides results for our preferred model that includes census-block fixed-effects when we split the sample by whether the properties are within the boundaries of LAUSD, which is the largest district in LA County, or all other school districts in the county. We may suspect there are different property effects for the two samples because LAUSD covers the main urban core of the county, and recent evidence suggests that urban charters are more effective than suburban charters (Angrist, Pathak and Walters, 2011). Our results, however, provide little evidence that house price effects vary via this location difference. Only one estimate - for charter counts in LAUSD from $1-1.5$ miles - is statistically significant.

Table 6 provides the results for equation (2), splitting the charter penetration variable by charter type - conversion and startup - for homes in all of LA County. As in our regression split by school district, we focus on our preferred model with census block fixed-effects, zoned elementary school controls, and housing controls. As in the pooled model, none of the 
coefficients are statistically significant and the magnitudes and signs of the estimates do not reveal a consistent relationship between charter counts or charter enrollment rates and sale price for either charter type.

In Table 7 we provide estimates that look at how charters affect house prices when we restrict the charters included in the count and enrollment share variables to those that are located in the same school district as the household. In California, within-district students get priority for charter enrollment and so there may be a stronger link with housing prices for these charters than those outside the district. We focus on districts outside of LAUSD as that district is especially large providing little differential variation from the estimates in Table 5 and as such when we estimate this model for LAUSD the estimates are little changed from baseline. The estimates in Table 7 are the only ones in this paper that provide a consistent indicator of a charter impact on housing prices. Intriguingly, this estimated effect is negative. An additional charter school within 2 miles reduces house prices by 1.9 percent while a 10 percentage point increase in charter share of enrollment within 0.5 miles reduces prices by 1.2 percent. This analysis provides some evidence that charters weaken the link between public schools and housing prices.

We build on this analysis further by testing whether we see larger effects in areas with higher quality schools. To test this, we provide results in Table A2 in the online appendix that estimate whether the marginal impacts of charters differ by census tract and home school characteristics. The estimates provide little evidence that the housing price reductions are larger in higher income or higher achieving zoned elementary schools (as measured by API scores) - if anything they are slightly larger in low income areas. An alternative explanation, as we noted, is that the break in this link reduces the value of any local public schooling good and thus could reduce housing prices regardless of the local school quality. Second, it is unclear to what extent 
this restriction to within district charters should matter. While district students get priority, this is only relevant if charters are over-subscribed. Hence, given the null results when we do not make this restriction we think it is best to consider these estimates to be a bound on the potential negative effect of charters.

\section{Testing for endogenous charter location}

A consistent estimate of the relationship between charter penetration and housing prices rests on the assumption that the variation in charter penetration is exogenous conditional on the included controls and, most important, the census block fixed-effects. As a test of this, we regress our limited set of housing characteristics on charter penetration variables and census block fixed effects. Ideally we would like to test the relationship between charter penetration and local neighborhood characteristics. However, including census block fixed-effects precludes such an analysis as we do not have access to time-varying neighborhood characteristics. Thus, we must rely on characteristics of the specific households that can be acquired from the property sales data.

Table 8 presents results that estimate whether charter penetration is related to square footage, the number of bedrooms, the number of bathrooms, and the quality of the structures on the property as measured by the county assessor. We find no statistically significant relationship between the numbers of charters in any radius ring and square footage, the number of bedrooms, or the number of bathrooms. For quality, only the estimate for charters between 1.5 and 2 miles is statistically significant and only at the $10 \%$ level. For charter seats as a percentage of all public education seats, no estimate is statistically significant. 
In a second analysis, we regress the log of house price on charter penetration within a half mile of the home in twelve month lag and lead intervals up to three years before the home was sold and three years after the home was sold. For example, the 12 month lag measure corresponds to charters within a half mile of the property that were in operation 12 months prior to the home's sale. The purpose of this analysis is to test for pre-existing trends and to see if there are any anticipatory or delayed impacts of charter openings. Thus, a clear pattern of higher prices from charters in operation after the house sale would be evidence of either anticipatory effects or preexisting trends in housing prices, the latter of which would invalidate the identification strategy. A pattern of higher prices from charters in operation prior to the home sale would indicate that housing prices are affected by charters but with a delay, potentially due to short-term price stickiness.

Table 9 provides the impacts of lags and leads, which show little evidence of responses to charter penetration. Of the two significant coefficients, one is for the 12 month lead in charter enrollment percentage that suggests an increase in enrollment rates of 10 percentage points within a half-mile of the property 12 months following the sale of the home increases the sale price by $0.3 \%$. While this could be indicative of a pre-existing trend, the other estimates indicate this is not likely to be the case. First, estimates for charter penetration 24 and 36 months after the sale show no impact. Second, there is no similar impact when measuring penetration using the number of charters. The other significant coefficient is for the 36 month lead in number of charters, suggesting an additional charter school within a half-mile of the property 36 months following the sale of the home increases the sale price by 1.9 percent. However, if this were indicative of an anticipatory response or pre-existing trend, we would expect to find significant impacts from charter penetration 24 months and 12 months after the sale, as well. Thus, while 
there are a couple estimates that indicate anticipatory responses or pre-trends, the bulk of the evidence in Table 7 argues against such a pattern. Further, we note that the results in the table also provide little indication of a delayed response since there is no significant impact from the number of charters open or the charter enrollment rates 12, 24 or 36 months prior to the sale.

Finally, in Table 10, we test the concern that the addition (or closure) of charter schools may generate sample selection by inducing some people to enter or stay out of the housing market. To do this we regress the number of annual sales in a census block on charter penetration near the block centroid. Further, even though we only have price data for the most recent sale of a property, we can see the dates for the three most recent sales. Thus in the second column we repeat the analysis using the three most recent sales of properties in the sales counts. The results show little impact of charter share of enrollment on housing sales. There is also no significant relationship between charter counts and sale counts within 1 mile of the centroid. Nonetheless, there is a statistically significant but economically small relationship between sales counts and the number of charters one to two miles from the centroid. The estimates suggest that, after conditioning on census block fixed-effects, a new charter opening one to two miles from the block centroid is related to an increase of 0.1 to 0.2 sales in a year. To put this in perspective it would take 5 to 10 new charter openings in a year to generate an additional sale. Given that the average number of charters in that distance range from properties is 1.9 , we believe this impact is too small to substantially affect our estimates.

Effect of charter penetration on housing prices: heterogeneity and specification checks.

In the online appendix we provide a series of analyses to look at impacts of charters when we allow the characteristics of the charters, local neighborhoods, and local public schools to 
vary. First, in Table A3 we provide different estimates by the grade level of the charter. Thus we split charter penetration measures into four categories - elementary, middle, high and multi-level schools. We see little evidence of differential impacts on housing prices by the level of the charter school at any distance up to two miles from the property. Only one estimate out of 32 is statistically significant at the 5\% level. Three more are significant at the $10 \%$ level, but show no clear pattern and differ in sign.

In Table A4 we interact the charter penetration measures with the year of the property sale. Since the housing market in Los Angeles had undergone substantial declines just prior to our study, we may be concerned that the lack of capitalization is due to abnormal rigidities in the market, though we note that the significant effects when we restrict to within-district charters suggests this is not the case. Nonetheless, to address this, we focus on the estimates for 2010 and 2011, well after the market had started its recovery. As with our main results, we find no statistically significant impacts of charter penetration at any distance within 2 miles of a property in 2010 or 2011. In fact only one estimate out of the 32 shown is statistically significant - 1 to 1.5 miles in 2008.

In Table A5 we provide evidence on whether the mean charter impacts may be hiding heterogeneous effects between neighborhoods with high performing and low performing schools by interacting the charter penetration variables with both the distance from the property and quartiles of household income (across all properties in the data) in the Census tract, the zoned elementary school's API score, percent minority enrollment in the zoned elementary school, and minority enrollment in the census tract. Only five estimates out of 128 are statistically significant at the $10 \%$ level ( 1 estimate at the $1 \%$ level) and do not show a clear pattern. Thus we see little indication our pooled estimates hiding heterogeneous impacts along these characteristics. 
Finally, in Table A6 we provide estimates under different specifications and sample restrictions. Through all of these specification and sample checks, no estimates are statistically significant. These checks include using sale price levels rather than log sale prices, splitting the sample by the number of bedrooms, keeping properties with more than 8 bedrooms in the regression, dropping large (5000 square feet or larger) properties, dropping multi-unit properties, and limiting to the summer months of June, July and August as families with children are more likely to move during this period between school-years. Further we show that adding a fifth distance ring of 2 to 5 miles does not change the estimates, nor is the estimate on the added ring significant and adding in school fixed-effects (in addition to census block fixed effects) has little impact on the baseline estimates.

\section{Conclusion}

Enrollment in charter schools has been increasing across the country over the past twenty years. Although conclusions on the effect of charters on student performance are mixed, it is likely charters will become an increasingly common education option for students. Thus, it is important to understand how local property markets react to these schools as changes in this market impact school district financing. If charters increase local property values this could help negate some of the negative fiscal impacts of charters on local public schools. However if they reduce property values, in many school districts this could make the financial challenges of dealing with charter schools worse.

To address this issue, we directly estimate how charter schools affect local property values. Additionally, we expand our analysis to separate our measures of charter penetration by urbanicity, charter type, and grade level of the school along with wealth of the local 
neighborhood and the achievement levels of the local elementary school. Our approach follows the work other researchers have done relating school characteristics to housing prices, and carefully accounts for the correlation between neighborhood characteristics and housing prices by including census block fixed effects. This method allows us to estimate the impacts of charters net of any time-invariant differences between local neighborhoods and, by extension, local public schools. Using data from Los Angeles County on property sale prices from 2008 through 2011, our estimates show that there is very little impact of charters on home prices on average. The results are not sensitive to sample selection or model specification, nor do we find differential impacts by whether a charter is a startup or conversion, whether the property is in the primary urban school district in the area, Los Angeles Unified School District, by the grade level of the charter, by the income level of the neighborhood, or by test scores in the zoned elementary school. However, given that in California over-subscribed charters must provide priority enrollment to students within the local school district, we also estimate a model that restricts to charters located in the same school district as the property. In this case, which we consider a negative lower-bound impact as it is not clear whether such a restriction is appropriate, we find some evidence that housing prices actually fall by 2 percent for each additional charter within two miles. Since evidence of differential impacts by school quality is weak and, at best, negatively related to income, this suggests that perhaps charter schools weaken the capitalization of schooling as a public good into property values rather than the capitalization of school quality in particular. 


\section{References}

Abdulkirolu, Atila, Joshua D. Angrist, Peter D. Hull, and Parag A. Pathak. 2014. "Charters

Without Lotteries: Testing Takeovers in New Orleans and Boston." NBER Working Paper No. 20800.

---, ---, Thomas J. Kane, and Parag A. Pathak. 2011. "Accountability and Flexibility in Public Schools: Evidence from Boston's Charters and Pilots." Quarterly Journal of Economics 126 (2): 699-748.

Angrist, Joshua D., Susan M. Dynarski, Thomas J. Kane, Parag A. Pathak, and Christopher R. Walters. 2012. "Who Benefits from KIPP?" Journal of Policy Analysis and Management 32(4): 837-860.

---, Parag A. Pathak, and Christopher R. Walters. 2011. "Explaining Charter School Effectiveness." NBER Working Paper \#17332.

Bayer, Patrick, Fernando Ferreira, and Robert McMillan. 2007. "A Unified Framework for Measuring Preferences for Schools and Neighborhoods." Journal of Political Economy 115(4): 588-638.

Bettinger, Eric P. 2005. "The Effect of Charter Schools on Charter Students and Public Schools." Economics of Education Review. 24(2): 133-147.

Bifulco, Robert, and Helen Ladd. 2006. "The impacts of charter schools on student achievement:

Evidence from North Carolina." Education Finance and Policy 1(1): 50-90.

Black, Sandra E. 1999. "Do Better Schools Matter? Parental Valuation of Elementary Education." Quarterly Journal of Economics 114(2): 577-599.

--- and Stephen Machin. 2011. "Housing Valuations of School Performance." in Eric A. Hanushek, Stephen Machin, and Ludger Woessmann (Eds.) Handbook of the Economics of Education, Volume 3. North-Holland: Amsterdam. 
Bogart, William T., and Brian A. Cromwell. 1997. "How much more is a good school district worth?" National Tax Journal 50:215-232.

--- and Brian A. Cromwell. 2000. "How much is a neighborhood school worth?." Journal of Urban Economics 47(2): 280-305.

Booker, Kevin, Scott Gilpatric, Timothy Gronberg, and Dennis Jansen. 2008. "The effect of charter schools on traditional public school students in Texas: Are children who stay behind left behind?" Journal of Urban Economics 64(1): 123-145.

Bradbury, Katharine L., Christopher J. Mayer, and Karl E. Case. 2001. "Property tax limits, local fiscal behavior, and property values: Evidence from Massachusetts under Proposition 212." Journal of Public Economics 80(2): 287-311.

Buddin, Richard, and Ronald Zimmer. 2005. "Student achievement in charter schools: A complex picture." Journal of Policy Analysis and Management 24(2): 351-371.

Buerger, Christian, 2014. "The impact of charter schools on housing values." Syracuse University, mimeo.

Cellini, Stephanie Riegg, Fernando Ferreira, and Jesse Rothstein. 2010. "The value of school facility investments: Evidence from a dynamic regression discontinuity design." The Quarterly Journal of Economics 125(1): 215-261.

Chakrabarti, Rajashri and Joydeep Roy. 2010. "Do charter schools crowd out private school enrollment? Evidence from Michigan." Federal Reserve Bank of New York Staff Report \#472.

Downes, Thomas A., and Jeffrey E. Zabel. 2002. "The impact of school characteristics on house prices: Chicago 1987-1991." Journal of Urban Economics 52(1): 1-25. 
Figlio, David N. and Maurice E. Lucas. 2004. "What's in a Grade? School Report Cards and the Housing Market." American Economic Review 94(3): 591-604.

Furgeson, Joshua, et al. 2012. “Charter-School Management Organizations: Diverse Strategies and Diverse Student Impacts." The National Study of Charter Management Organization (CMO) Effectiveness. Technical report. Mathematica Policy Research and the Center on Reinventing Public Education.

Gibbons, Stephen, and Stephen Machin. 2003. "Valuing English Primary Schools." Journal of Urban Economics 53(2): 197-219.

---, --- and Olmo Silva. 2013. "Valuing School Quality Using Boundary Discontinuities." Journal of Urban Economics 75: 15-28.

Hanushek, Eric A., John Kain, Steven Rivkin, and Gregory Branch. 2007. "Charter school quality and parental decision making with school choice." Journal of Public Economics 91(5): 823-848.

Imberman, Scott A., 2011. "The Effect of Charter Schools on Achievement and Behavior of Public School Students" Journal of Public Economics 95(7-8).

---, 2011. "Achievement and Behavior in Charter Schools: Drawing a More Complete Picture.” The Review of Economics and Statistics, 93(2).

--- and Lovenheim, Michael F., 2013. "Does the Market Value Value-Added? Evidence From Housing Prices After a Public Release of School and Teacher Value-Added." NBER Working Paper \#1915.

Kane, Thomas J., Stephanie K. Riegg and Douglas O. Staiger. 2006. "School Quality Neighborhoods, and Housing Prices." American Law and Economic Review 8(2): 183-212. 
Lubienski, Christopher. 2003. "Innovation in education markets: Theory and evidence on the impact of competition and choice in charter schools." American Educational Research Journal 40(2): 395-443.

Nechyba, Thomas J. 2003. "Introducing School Choice into Multidistrict Public School Systems," in The Economics of School Choice, Caroline M. Hoxby, ed. University of Chicago Press.

Oates, Wallace E. 1969. "The effects of property taxes and local public spending on property values: An empirical study of tax capitalization and the Tiebout hypothesis" Journal of Political Economy 77:957-971.

Reback, Randall. 2005. "House prices and the provision of local public services: capitalization under school choice programs." Journal of Urban Economics 57(2): 275-301.

Rosen, Sherwin. 1974. "Hedonic Prices and Implicit Markets - Product Differentiation in Pure Competition." Journal of Political Economy 82(1): 34-55.

Sass, Tim R. 2006. "Charter schools and student achievement in Florida." Education Finance and Policy 1(1): 91-122.

Walters, Christopher R. 2014. "The Demand for Effective Charter Schools.” NBER Working Paper No. 20640.

Weimer, David, and Michael Wolkoff. 2001. "School performance and housing values: Using non-contiguous district and incorporation boundaries to identify school effects." National Tax Journal 54(3): 231-253.

Zimmer, Ron, and Richard Buddin. 2006. "Charter school performance in two large urban districts." Journal of Urban Economics 60(2), 307-326. 
---, and Richard Buddin. 2009. "Is charter school competition in California improving the performance of traditional public schools?" Public Administration Review 69(5), 831-845. 


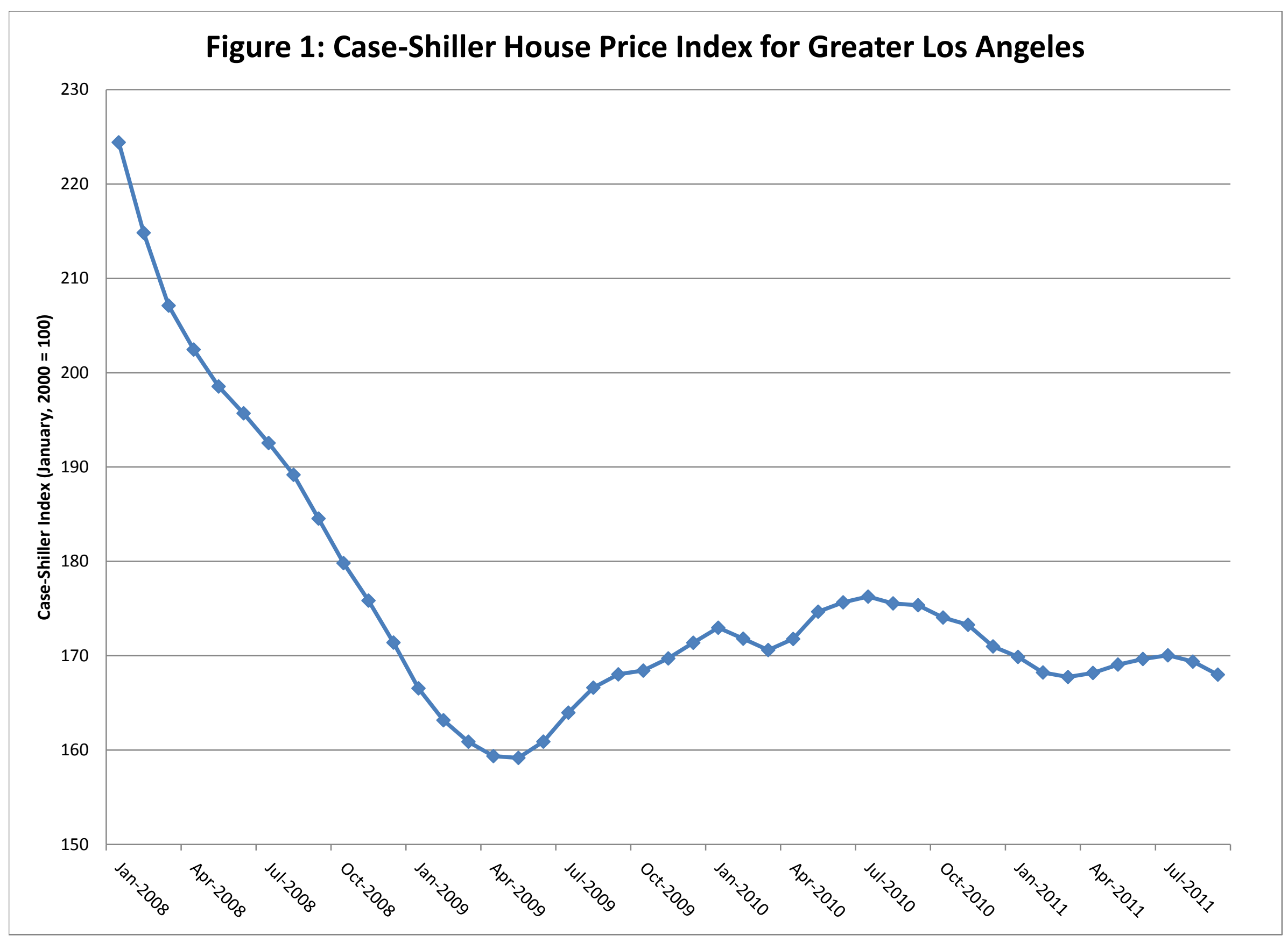


Figure 2 - Distribution of House Sales by Census Block During Sample Period Conditional on Census Block Having Any Sales

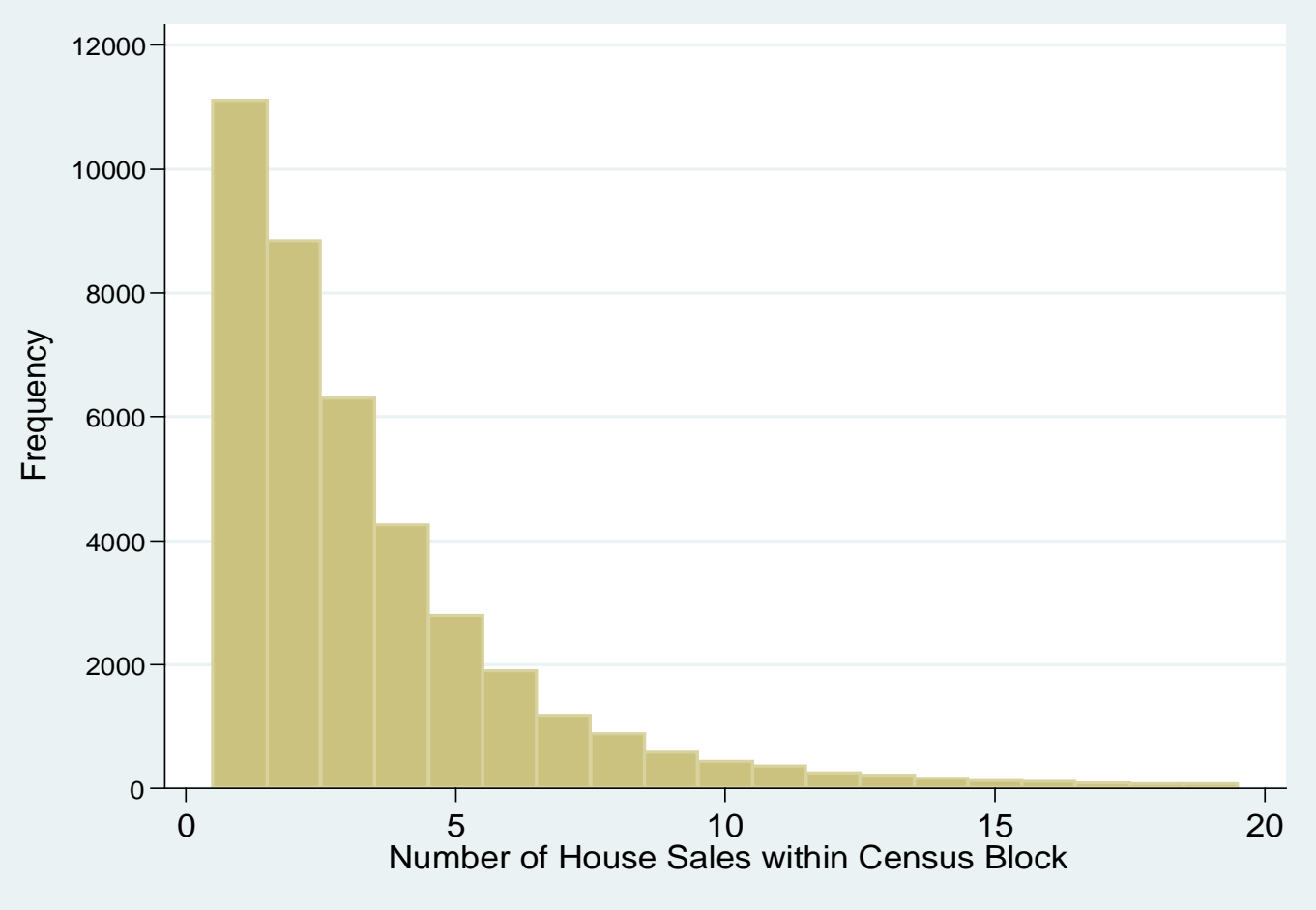


Table 1: Schools in LA County

\begin{tabular}{|c|c|c|c|c|}
\hline \multicolumn{5}{|c|}{ A. Schools by Grade Level } \\
\hline & Elementary & Middle & High & $\begin{array}{c}\text { Multiple } \\
\text { Levels }\end{array}$ \\
\hline Non-charter public schools & 1,196 & 243 & 390 & 68 \\
\hline Total charter schools & 113 & 48 & 88 & 35 \\
\hline \% Charter Schools & $8.6 \%$ & $16.5 \%$ & $18.4 \%$ & $34.0 \%$ \\
\hline Conversion charters & 21 & 1 & 10 & 3 \\
\hline Start-up charters & 92 & 47 & 78 & 32 \\
\hline \multicolumn{5}{|c|}{ B. Schools by Years of Operation } \\
\hline & $\begin{array}{c}\text { Non-Charter } \\
\text { Public }\end{array}$ & Conversion & Start-up & $\begin{array}{l}\text { \% Charter } \\
\text { Schools }\end{array}$ \\
\hline 2008 & 1,743 & 19 & 127 & $7.7 \%$ \\
\hline 2009 & 1,758 & 23 & 147 & $8.8 \%$ \\
\hline 2010 & 1,777 & 24 & 181 & $10.3 \%$ \\
\hline 2011 & 1,809 & 26 & 213 & $11.7 \%$ \\
\hline
\end{tabular}

Note: Schools included in panel A are those open and active at any point September 2008 through September 2011. Data obtained from California Department of Education. 


\section{Table 2: Summary Statistics of Properties with Sale Prices}

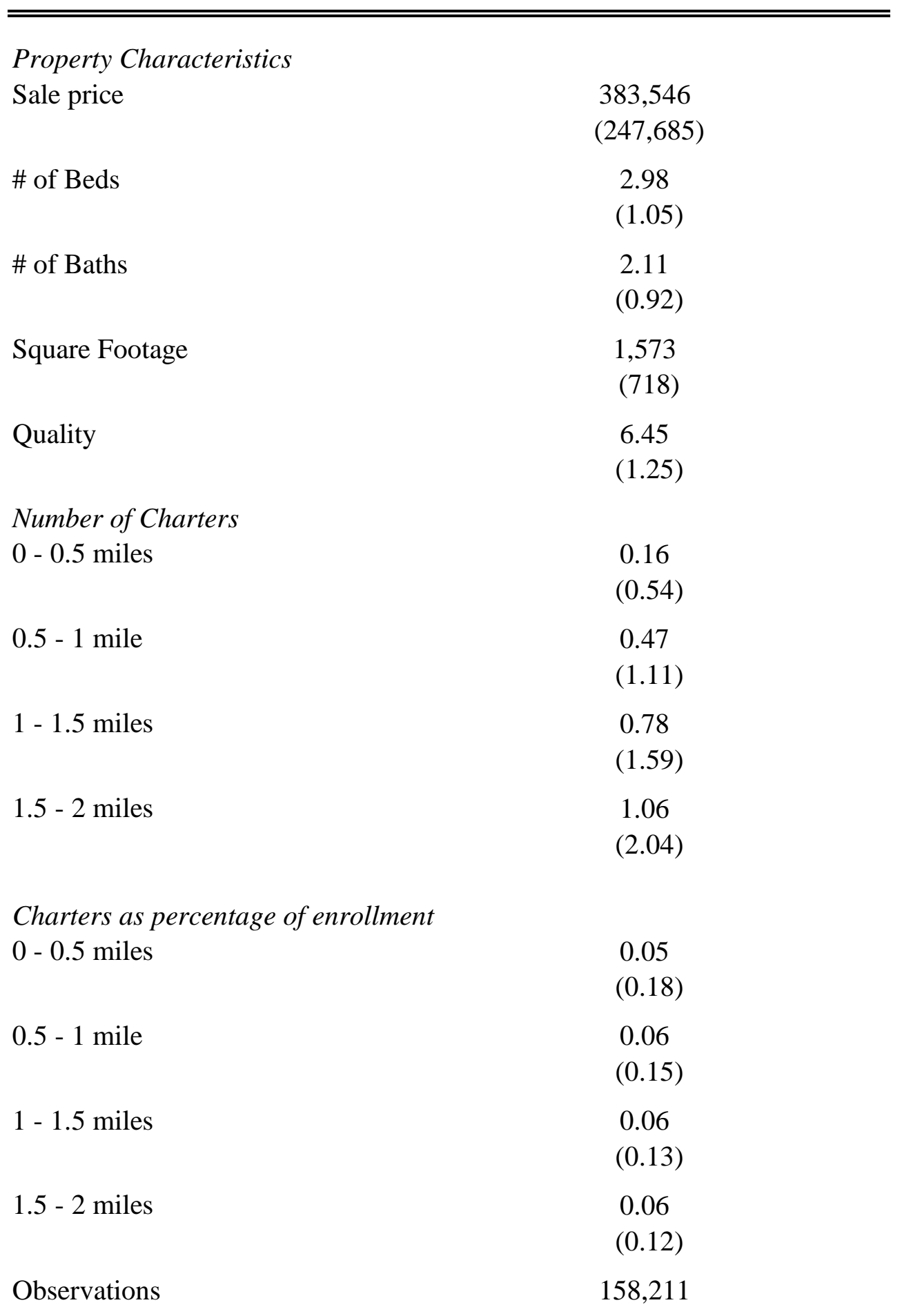

Notes: Summary statistics are means for sales from September 2008 through September 2011. Property sample excludes homes with a sale price exceeding \$1.5 million, and a bedroom or bathroom count in excess of eight. Homes are divided into the "LAUSD" or "Rest of LA County" samples via the location of the elementary school to which the property is zoned. Standard deviations in parentheses. 
Table 3: Summary Statistics - Schools Near Properties with Sale Prices

\begin{tabular}{|c|c|c|c|c|c|c|}
\hline & \multicolumn{3}{|c|}{ A: Characteristics of zoned school } & \multicolumn{3}{|c|}{$\begin{array}{c}\text { B: Characteristics of charters within } 1 \text { mile of } \\
\text { property (enrollment weighted) }\end{array}$} \\
\hline & Elementary & Middle & High & Elementary & Middle & High \\
\hline Enrollment & $\begin{array}{l}440.5 \\
(165.6)\end{array}$ & $\begin{array}{r}1,197.4 \\
(488.0)\end{array}$ & $\begin{array}{r}2,002.6 \\
(680.6)\end{array}$ & $\begin{array}{l}443.0 \\
(138.0)\end{array}$ & $\begin{array}{r}1,121.3 \\
(435.7)\end{array}$ & $\begin{array}{r}1,140.5 \\
(814.3)\end{array}$ \\
\hline API Score & $\begin{array}{l}805.6 \\
(73.6)\end{array}$ & $\begin{array}{l}746.1 \\
(90.3)\end{array}$ & $\begin{array}{l}707.0 \\
(88.2)\end{array}$ & $\begin{array}{l}800.1 \\
(64.5)\end{array}$ & $\begin{array}{l}744.7 \\
(93.0)\end{array}$ & $\begin{array}{l}663.7 \\
(112.4)\end{array}$ \\
\hline \% Black & $\begin{array}{l}10.9 \\
(14.4)\end{array}$ & $\begin{array}{l}10.1 \\
(11.9)\end{array}$ & $\begin{array}{l}11.2 \\
(13.3)\end{array}$ & $\begin{array}{l}10.6 \\
(13.2)\end{array}$ & $\begin{array}{l}10.3 \\
(11.6)\end{array}$ & $\begin{array}{l}11.1 \\
(12.6)\end{array}$ \\
\hline \% Hispanic & $\begin{array}{l}58.2 \\
(28.5)\end{array}$ & $\begin{array}{l}62.9 \\
(24.7)\end{array}$ & $\begin{array}{l}60.1 \\
(24.8)\end{array}$ & $\begin{array}{l}62.0 \\
(25.7)\end{array}$ & $\begin{array}{c}63.6 \\
(25.2)\end{array}$ & $\begin{array}{l}65.2 \\
(23.9)\end{array}$ \\
\hline$\%$ Asian & $\begin{array}{c}7.1 \\
(12.6)\end{array}$ & $\begin{array}{l}7.0 \\
(12.0)\end{array}$ & $\begin{array}{c}7.6 \\
(12.3)\end{array}$ & $\begin{array}{c}7.2 \\
(12.0)\end{array}$ & $\begin{array}{c}7.7 \\
(13.2)\end{array}$ & $\begin{array}{c}5.9 \\
(11.5)\end{array}$ \\
\hline \% Disabled & $\begin{array}{l}11.4 \\
(4.5)\end{array}$ & $\begin{array}{l}11.4 \\
(2.8)\end{array}$ & $\begin{array}{l}10.3 \\
(3.1)\end{array}$ & $\begin{array}{l}11.8 \\
(4.1)\end{array}$ & $\begin{array}{l}11.1 \\
(2.7)\end{array}$ & $\begin{array}{l}10.6 \\
(12.2)\end{array}$ \\
\hline \% Gifted & $\begin{array}{l}8.4 \\
(7.3)\end{array}$ & $\begin{array}{l}13.8 \\
(9.7)\end{array}$ & $\begin{array}{l}11.4 \\
(8.8)\end{array}$ & $\begin{array}{l}7.5 \\
(5.4)\end{array}$ & $\begin{array}{l}12.6 \\
(8.6)\end{array}$ & $\begin{array}{l}7.3 \\
(7.0)\end{array}$ \\
\hline $\begin{array}{l}\text { \% Free or Reduced } \\
\text { Price Lunch }\end{array}$ & $\begin{array}{l}64.7 \\
(30.0)\end{array}$ & $\begin{array}{l}66.9 \\
(25.7)\end{array}$ & $\begin{array}{l}55.9 \\
(26.9)\end{array}$ & $\begin{array}{l}68.7 \\
(26.6)\end{array}$ & $\begin{array}{l}67.5 \\
(26.6)\end{array}$ & $\begin{array}{l}61.2 \\
(24.1)\end{array}$ \\
\hline $\begin{array}{l}\text { \% English Language } \\
\text { Learner }\end{array}$ & $\begin{array}{l}28.1 \\
(17.2)\end{array}$ & $\begin{array}{l}19.8 \\
(11.5)\end{array}$ & $\begin{array}{l}18.0 \\
(10.5)\end{array}$ & $\begin{array}{l}30.3 \\
(15.2)\end{array}$ & $\begin{array}{l}20.2 \\
(11.7)\end{array}$ & $\begin{array}{l}20.8 \\
(12.2)\end{array}$ \\
\hline $\begin{array}{l}\text { Observations } \\
\text { for api score: }\end{array}$ & $\begin{array}{l}158,211 \\
158,211\end{array}$ & $\begin{array}{l}127,558 \\
127,174\end{array}$ & $\begin{array}{l}141,212 \\
140,866\end{array}$ & $\begin{array}{l}136,546 \\
136,536\end{array}$ & $\begin{array}{l}81,204 \\
80,686\end{array}$ & $\begin{array}{l}83,079 \\
80,979\end{array}$ \\
\hline
\end{tabular}

Notes: Summary statistics are means for sales from September 2008 through September 2011. Sample excludes homes with a sale price exceeding \$1.5 million, and a bedroom or bathroom count in excess of eight. School zones are based on 2002 zoning. See text for details on how to access school zone maps. Standard deviations in parentheses. 
Table 4 - Effect of Charters on Log Sale Prices for Los Angeles County

\begin{tabular}{|c|c|c|c|c|c|c|}
\hline & \multicolumn{6}{|c|}{ LA County } \\
\hline & \multicolumn{3}{|c|}{ Number of charters } & \multicolumn{3}{|c|}{$\begin{array}{c}\text { Charter seats as percentage of } \\
\text { enrollment }\end{array}$} \\
\hline & (i) & (ii) & (iii) & (iv) & (v) & (vi) \\
\hline A. Distance gradient & & & & & & \\
\hline $0-0.5$ miles & $\begin{array}{l}-0.0073 \\
(0.0131)\end{array}$ & $\begin{array}{l}-0.0353^{* * *} \\
(0.0080)\end{array}$ & $\begin{array}{l}-0.0054 \\
(0.0083)\end{array}$ & $\begin{array}{l}0.0741^{*} \\
(0.0438)\end{array}$ & $\begin{array}{c}0.0065 \\
(0.0249)\end{array}$ & $\begin{array}{l}-0.0013 \\
(0.0194)\end{array}$ \\
\hline 0.5 - 1 mile & $\begin{array}{c}0.0086 \\
(0.0075)\end{array}$ & $\begin{array}{c}-0.0253^{* * *} \\
(0.0061)\end{array}$ & $\begin{array}{c}0.0010 \\
(0.0048)\end{array}$ & $\begin{array}{l}0.1170^{* *} \\
(0.0564)\end{array}$ & $\begin{array}{l}-0.0166 \\
(0.0270)\end{array}$ & $\begin{array}{l}-0.0128 \\
(0.0195)\end{array}$ \\
\hline 1 - 1.5 miles & $\begin{array}{c}0.0252^{* * *} \\
(0.0058)\end{array}$ & $\begin{array}{c}-0.0149 * * * \\
(0.0039)\end{array}$ & $\begin{array}{c}0.0022 \\
(0.0031)\end{array}$ & $\begin{array}{c}0.1400^{* *} \\
(0.0616)\end{array}$ & $\begin{array}{l}-0.0442 * \\
(0.0268)\end{array}$ & $\begin{array}{l}-0.0123 \\
(0.0239)\end{array}$ \\
\hline 1.5 - 2 miles & $\begin{array}{c}0.0239 * * * \\
(0.0049)\end{array}$ & $\begin{array}{c}-0.0046 \\
(0.0031)\end{array}$ & $\begin{array}{l}-0.0011 \\
(0.0028)\end{array}$ & $\begin{array}{c}0.1200 \\
(0.0770)\end{array}$ & $\begin{array}{l}-0.0217 \\
(0.0340)\end{array}$ & $\begin{array}{l}-0.0047 \\
(0.0255)\end{array}$ \\
\hline $\begin{array}{l}\text { B. Condensed 0-2 miles } \\
0-2 \text { miles }\end{array}$ & $\begin{array}{c}0.0193 * * * \\
(0.0032)\end{array}$ & $\begin{array}{c}-0.0101^{* * *} \\
(0.0026)\end{array}$ & $\begin{array}{c}0.0001 \\
(0.0021)\end{array}$ & $\begin{array}{c}0.3280^{* * *} \\
(0.1120)\end{array}$ & $\begin{array}{l}-0.0301 \\
(0.0609)\end{array}$ & $\begin{array}{l}-0.0075 \\
(0.0544)\end{array}$ \\
\hline Observations & 158,211 & 158,211 & 158,211 & 158,211 & 158,211 & 158,211 \\
\hline Housing Characteristics & $\mathrm{Y}$ & Y & $\mathrm{Y}$ & $\mathrm{Y}$ & $\mathrm{Y}$ & $\mathrm{Y}$ \\
\hline School Characteristics & $\mathrm{Y}$ & $\mathrm{Y}$ & $\mathrm{Y}$ & $\mathrm{Y}$ & $\mathrm{Y}$ & $\mathrm{Y}$ \\
\hline School Fixed-Effects & $\mathrm{N}$ & $\mathrm{Y}$ & $\mathrm{N}$ & $\mathrm{N}$ & $\mathrm{Y}$ & $\mathrm{N}$ \\
\hline Census Block Fixed-Effects & $\mathrm{N}$ & $\mathrm{N}$ & $\mathrm{Y}$ & $\mathrm{N}$ & $\mathrm{N}$ & $\mathrm{Y}$ \\
\hline
\end{tabular}

Sample includes property sales from April 2009 through September, 2011. The independent variable denotes either the number of charters in operation or the share of enrollment in operating charters as of the sale date in various distance rings from the property. Housing chracteristics include number of bedrooms, bathrooms, square footage, and quality. School chracteristics include API levels overall, lags and second lags of overall API scores, \% of students of each race, \% free lunch, \% gifted, \% English language learners, \% disabled, and parent education levels for elementary school zoned to the property in 2002. All regressions include month-by-year fixed-effects. Robust standard errors clustered by elementary school zone in 2002 in parentheses. *, **, and *** denote significance at the $10 \%, 5 \%$ and $1 \%$ levels, respectively. 
Table 5: Effect of Charters on Log Sale Prices for Los Angeles County by School District

\begin{tabular}{|c|c|c|c|c|}
\hline & \multicolumn{2}{|c|}{ LAUSD } & \multicolumn{2}{|c|}{ Rest of LA County } \\
\hline & Number of charters & $\begin{array}{c}\text { Charter seats as } \\
\text { percentage of } \\
\text { enrollment }\end{array}$ & Number of charters & $\begin{array}{c}\text { Charter seats as } \\
\text { percentage of } \\
\text { enrollment }\end{array}$ \\
\hline 0 - 0.5 miles & $\begin{array}{c}0.0005 \\
(0.0097)\end{array}$ & $\begin{array}{c}0.0092 \\
(0.0236)\end{array}$ & $\begin{array}{l}-0.0143 \\
(0.0169)\end{array}$ & $\begin{array}{l}-0.0220 \\
(0.0373)\end{array}$ \\
\hline 0.5 - 1 mile & $\begin{array}{c}0.0059 \\
(0.0056)\end{array}$ & $\begin{array}{c}-0.0062 \\
(0.0278)\end{array}$ & $\begin{array}{l}-0.0045 \\
(0.0087)\end{array}$ & $\begin{array}{c}-0.0114 \\
(0.0241)\end{array}$ \\
\hline 1 - 1.5 miles & $\begin{array}{c}0.0071^{* *} \\
(0.0035)\end{array}$ & $\begin{array}{c}-0.0061 \\
(0.0314)\end{array}$ & $\begin{array}{c}-0.0023 \\
(0.0063)\end{array}$ & $\begin{array}{c}0.000579 \\
(0.0351)\end{array}$ \\
\hline 1.5 - 2 miles & $\begin{array}{c}0.0023 \\
(0.0034)\end{array}$ & $\begin{array}{c}-0.0130 \\
(0.0408)\end{array}$ & $\begin{array}{c}-0.0038 \\
(0.0047)\end{array}$ & $\begin{array}{c}0.0259 \\
(0.0206)\end{array}$ \\
\hline Observations & 65,170 & 65,170 & 93,041 & 93,041 \\
\hline R-squared & 0.83 & 0.83 & 0.91 & 0.91 \\
\hline Housing Characteristics & $\mathrm{Y}$ & $\mathrm{Y}$ & $\mathrm{Y}$ & $\mathrm{Y}$ \\
\hline School Characteristics & $\mathrm{Y}$ & $\mathrm{Y}$ & $\mathrm{Y}$ & $\mathrm{Y}$ \\
\hline School Fixed-Effects & $\mathrm{N}$ & $\mathrm{N}$ & $\mathrm{N}$ & $\mathrm{N}$ \\
\hline Census Block Fixed-Effects & $\mathrm{Y}$ & $\mathrm{Y}$ & $\mathrm{Y}$ & $\mathrm{Y}$ \\
\hline
\end{tabular}

Notes: See Table 4 for a description of baseline sample and controls. Robust standard errors clustered by elementary school zone in 2002 in parentheses. *, **, and *** denote significance at the 10\%, 5\% and 1\% levels, respectively. 
Table 6: Effect of Charters on Log Sale Prices by Charter Type

\begin{tabular}{|c|c|c|}
\hline & \multicolumn{2}{|c|}{ LA County } \\
\hline & Number of charters & $\begin{array}{c}\text { Charter seats as percentage } \\
\text { of enrollment }\end{array}$ \\
\hline \multicolumn{3}{|l|}{$\overline{\text { Start-up charters }}$} \\
\hline 0 - 0.5 miles & $\begin{array}{l}-0.0045 \\
(0.0095)\end{array}$ & $\begin{array}{c}0.0039 \\
(0.0226)\end{array}$ \\
\hline 0.5 - 1 mile & $\begin{array}{c}0.0025 \\
(0.0054)\end{array}$ & $\begin{array}{c}0.0009 \\
(0.0241)\end{array}$ \\
\hline 1 - 1.5 miles & $\begin{array}{c}0.0034 \\
(0.0036)\end{array}$ & $\begin{array}{c}0.0027 \\
(0.0240)\end{array}$ \\
\hline 1.5 - 2 miles & $\begin{array}{l}-0.0011 \\
(0.0030)\end{array}$ & $\begin{array}{c}0.0273 \\
(0.0234)\end{array}$ \\
\hline \multicolumn{3}{|l|}{ Conversion charters } \\
\hline 0 - 0.5 miles & $\begin{array}{l}-0.0137 \\
(0.0133)\end{array}$ & $\begin{array}{l}-0.0226 \\
(0.0362)\end{array}$ \\
\hline 0.5 - 1 mile & $\begin{array}{l}-0.0110 \\
(0.0103)\end{array}$ & $\begin{array}{l}-0.0432 \\
(0.0311)\end{array}$ \\
\hline 1 - 1.5 miles & $\begin{array}{l}-0.0066 \\
(0.0085)\end{array}$ & $\begin{array}{l}-0.0397 \\
(0.0456)\end{array}$ \\
\hline 1.5 - 2 miles & $\begin{array}{l}-0.0023 \\
(0.0079)\end{array}$ & $\begin{array}{l}-0.0506 \\
(0.0513)\end{array}$ \\
\hline Observations & 158,211 & 158,211 \\
\hline Housing Characteristics & $\mathrm{Y}$ & $\mathrm{Y}$ \\
\hline School Characteristics & $\mathrm{Y}$ & $\mathrm{Y}$ \\
\hline School Fixed-Effects & $\mathrm{N}$ & $\mathrm{N}$ \\
\hline Census Block Fixed-Effects & $\mathrm{Y}$ & $\mathrm{Y}$ \\
\hline
\end{tabular}

Notes: See Table 4 for a description of baseline sample and controls. Robust standard errors clustered by elementary school zone in 2002 in parentheses. *, **, and *** denote significance at the $10 \%, 5 \%$ and $1 \%$ levels, respectively. 
Table 7: Effect of Charters Within the Home's School District on Log Sale Prices for Los Angeles County Excluding LAUSD

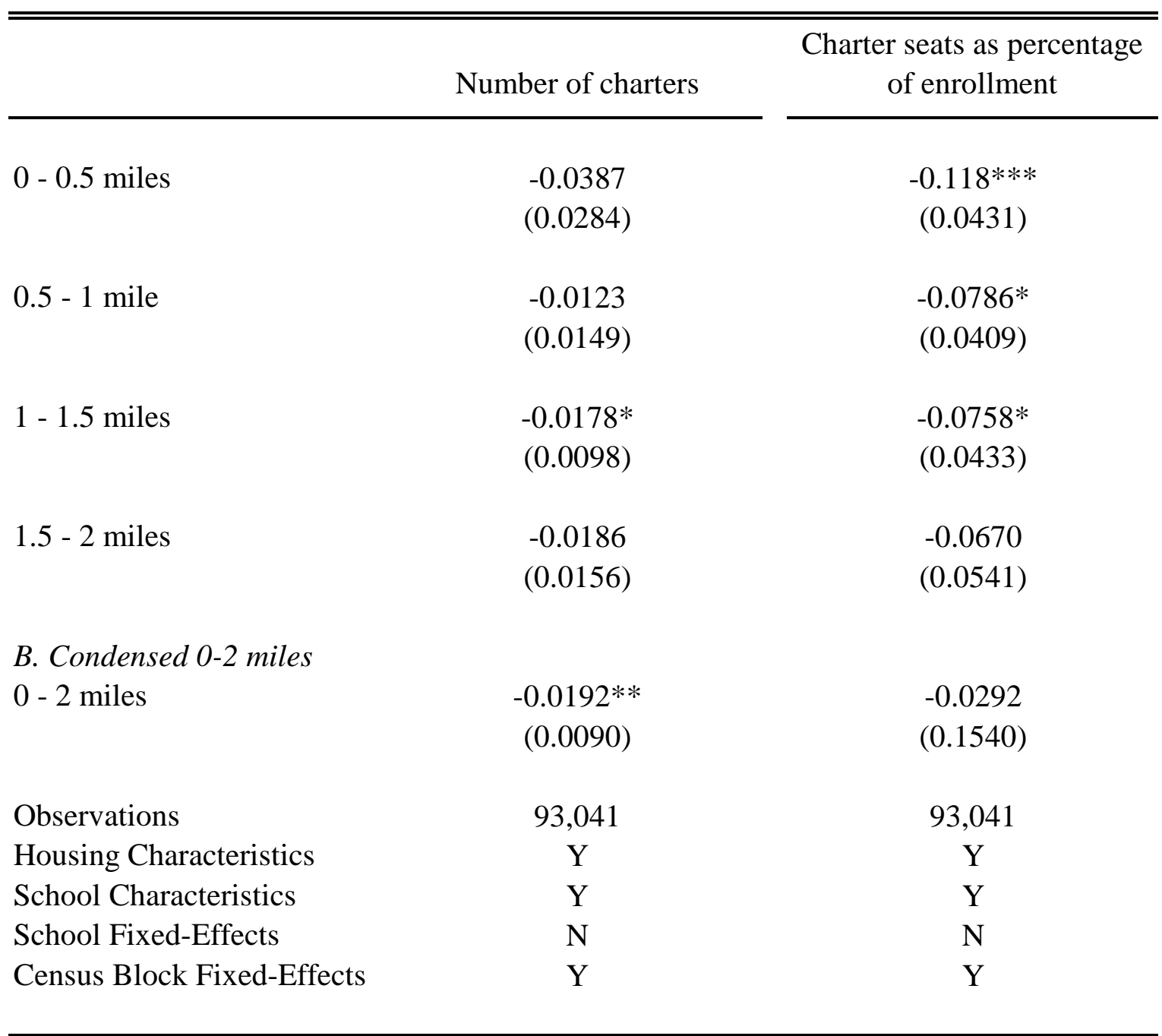

Sample includes property sales from April 2009 through September, 2011. The independent variable denotes either the number of charters within the home's zoned school district in operation or the share of enrollment in operating charters as of the sale date in various distance rings from the property. Housing chracteristics include number of bedrooms, bathrooms, square footage, and quality. School chracteristics include API levels overall, lags and second lags of overall API scores, \% of students of each race, \% free lunch, \% gifted, \% English language learners, \% disabled, and parent education levels for elementary school zoned to the property in 2002. All regressions include month-byyear fixed-effects. Robust standard errors clustered by elementary school zone in 2002 in parentheses. *, **, and *** denote significance at the $10 \%, 5 \%$ and $1 \%$ levels, respectively. 
Table 8: Impacts of Charters on Exogenous Observables

\begin{tabular}{|c|c|c|c|c|}
\hline \multirow[b]{2}{*}{ Number of charters } & \multicolumn{4}{|c|}{ LA County } \\
\hline & Square footage & \# of Beds & \# of Baths & Quality \\
\hline 0 - 0.5 miles & $\begin{array}{c}3.9 \\
(14.0)\end{array}$ & $\begin{array}{c}0.0147 \\
(0.0247)\end{array}$ & $\begin{array}{c}0.0186 \\
(0.0192)\end{array}$ & $\begin{array}{c}0.0124 \\
(0.0172)\end{array}$ \\
\hline 0.5 - 1 mile & $\begin{array}{l}-6.6 \\
(7.4)\end{array}$ & $\begin{array}{l}-0.0112 \\
(0.0147)\end{array}$ & $\begin{array}{l}-0.0183 \\
(0.0112)\end{array}$ & $\begin{array}{l}-0.0096 \\
(0.0098)\end{array}$ \\
\hline 1 - 1.5 miles & $\begin{array}{c}5.0 \\
(5.0)\end{array}$ & $\begin{array}{c}0.0116 \\
(0.0098)\end{array}$ & $\begin{array}{c}0.0045 \\
(0.0074)\end{array}$ & $\begin{array}{l}-0.0086 \\
(0.0066)\end{array}$ \\
\hline 1.5 - 2 miles & $\begin{array}{l}-2.4 \\
(4.8)\end{array}$ & $\begin{array}{l}-0.0015 \\
(0.0097)\end{array}$ & $\begin{array}{l}0.0001 \\
(0.007)\end{array}$ & $\begin{array}{l}-0.0120 * \\
(0.0065)\end{array}$ \\
\hline Observations & 158,211 & 158,211 & 158,211 & 158,211 \\
\hline $\begin{array}{l}\text { Charter seats as percentage of } \\
\text { enrollment }\end{array}$ & Square footage & \# of Beds & \# of Baths & Quality \\
\hline 0 - 0.5 miles & $\begin{array}{l}-22.7 \\
(37.3)\end{array}$ & $\begin{array}{l}-0.005 \\
(0.048)\end{array}$ & $\begin{array}{c}0.023 \\
(0.040)\end{array}$ & $\begin{array}{c}0.025 \\
(0.046)\end{array}$ \\
\hline 0.5 - 1 mile & $\begin{array}{c}25.6 \\
(40.6)\end{array}$ & $\begin{array}{c}0.011 \\
(0.062)\end{array}$ & $\begin{array}{c}0.023 \\
(0.050)\end{array}$ & $\begin{array}{l}-0.037 \\
(0.05)\end{array}$ \\
\hline 1 - 1.5 miles & $\begin{array}{c}28.5 \\
(39.5)\end{array}$ & $\begin{array}{c}0.011 \\
(0.057)\end{array}$ & $\begin{array}{l}-0.009 \\
(0.051)\end{array}$ & $\begin{array}{l}-0.021 \\
(0.050)\end{array}$ \\
\hline 1.5 - 2 miles & $\begin{array}{l}-23.4 \\
(43.2)\end{array}$ & $\begin{array}{c}-0.044 \\
(0.052)\end{array}$ & $\begin{array}{c}-0.046 \\
(0.052)\end{array}$ & $\begin{array}{c}0.000 \\
(0.049)\end{array}$ \\
\hline Observations & 158,211 & 158,211 & 158,211 & 158,211 \\
\hline R-squared & 0.67 & 0.55 & 0.59 & 0.80 \\
\hline School Fixed-Effects & $\mathrm{N}$ & $\mathrm{N}$ & $\mathrm{N}$ & $\mathrm{N}$ \\
\hline Census Block Fixed-Effects & $\mathrm{Y}$ & $\mathrm{Y}$ & $\mathrm{Y}$ & $\mathrm{Y}$ \\
\hline
\end{tabular}

Notes: See Table 4 for a description of baseline sample. Robust standard errors clustered by elementary school zone in 2002 in parentheses. *, **, and *** denote significance at the 10\%, 5\% and $1 \%$ levels, respectively. 
Table 9: Effect of Lags and Leads of Charter Penetration

\begin{tabular}{|c|c|c|}
\hline & \multicolumn{2}{|c|}{ LA County } \\
\hline & Number of charters & $\begin{array}{c}\text { Charter seats as percentage of } \\
\text { enrollment }\end{array}$ \\
\hline \multirow[t]{2}{*}{36 months prior to sale } & -0.0005 & -0.001 \\
\hline & $(0.0100)$ & $(0.027)$ \\
\hline \multirow[t]{2}{*}{24 months prior to sale } & -0.0039 & -0.017 \\
\hline & $(0.0093)$ & $(0.031)$ \\
\hline \multirow[t]{2}{*}{12 months prior to sale } & -0.0055 & -0.008 \\
\hline & $(0.0089)$ & $(0.030)$ \\
\hline \multirow[t]{2}{*}{ Time of sale } & -0.0010 & 0.006 \\
\hline & $(0.0088)$ & $(0.031)$ \\
\hline \multirow[t]{2}{*}{12 months after sale } & 0.0038 & $0.033 * *$ \\
\hline & $(0.0054)$ & $(0.015)$ \\
\hline \multirow[t]{2}{*}{24 months after sale } & -0.0082 & -0.019 \\
\hline & $(0.0080)$ & $(0.025)$ \\
\hline \multirow[t]{2}{*}{36 months after sale } & $0.0190 *$ & 0.013 \\
\hline & $(0.0102)$ & $(0.037)$ \\
\hline Observations & 158,211 & 158,211 \\
\hline R-squared & 0.88 & 0.88 \\
\hline
\end{tabular}

Notes: See Table 4 for a description of baseline sample and controls. Robust standard errors clustered by elementary school zone in 2002 in parentheses. *, **, and *** denote significance at the $10 \%, 5 \%$ and $1 \%$ levels, respectively. 
Table 10: Relationship Between Charter Penetration and the Number of Annual House Sales in Census Block

\begin{tabular}{|c|c|c|c|c|}
\hline & \multicolumn{4}{|c|}{ Quantity of House Sales within Census Block } \\
\hline & \multicolumn{2}{|c|}{ Counting Most Recent House Sale } & \multicolumn{2}{|c|}{$\begin{array}{c}\text { Counting Three Most Recent House } \\
\text { Sales } \\
\end{array}$} \\
\hline & $\begin{array}{c}\text { Number of } \\
\text { Charters }\end{array}$ & $\begin{array}{l}\text { Charter seats as } \\
\text { percentage of } \\
\text { enrollment }\end{array}$ & $\begin{array}{c}\text { Number of } \\
\text { Charters }\end{array}$ & $\begin{array}{c}\text { Charter seats as } \\
\text { percentage of } \\
\text { enrollment }\end{array}$ \\
\hline \multirow[t]{2}{*}{0 - 0.5 miles } & 0.0828 & 0.354 & 0.0901 & 0.346 \\
\hline & $(0.168)$ & $(0.414)$ & $(0.174)$ & $(0.417)$ \\
\hline \multirow[t]{2}{*}{0.5 - 1 mile } & 0.119 & 0.346 & 0.130 & 0.391 \\
\hline & $(0.110)$ & $(0.533)$ & $(0.110)$ & $(0.537)$ \\
\hline \multirow[t]{2}{*}{1 - 1.5 miles } & $0.139 *$ & 0.581 & $0.171^{* *}$ & 0.801 \\
\hline & $(0.078)$ & $(0.647)$ & $(0.079)$ & $(0.721)$ \\
\hline \multirow[t]{2}{*}{1.5 - 2 miles } & $0.097^{*}$ & -0.010 & $0.121 * *$ & 0.120 \\
\hline & $(0.055)$ & $(0.607)$ & $(0.055)$ & $(0.659)$ \\
\hline Observations & 87,683 & 87,683 & 87,683 & 87,683 \\
\hline Census Block Fixed-Effects & $\mathrm{Y}$ & $\mathrm{Y}$ & $\mathrm{Y}$ & $\mathrm{Y}$ \\
\hline
\end{tabular}

Sample includes property sales from September 2008 through September, 2011. The independent variable denotes either the number of charters in operation or the share of enrollment in operating charters as of the sale date in various distance rings from the property. Robust standard errors clustered by elementary school zone in 2002 in parentheses. ${ }^{*}, * *$, and $* * *$ denote significance at the $10 \%, 5 \%$ and $1 \%$ levels, respectively. 
Online Appendix:

Not for Publication 
Table A1: Relationship Between Charters in a School Zone and Elementary School Characteristics

\begin{tabular}{|c|c|c|}
\hline & $\begin{array}{l}\text { Count of Open Charters within } \\
\text { Local School Zone }\end{array}$ & $\begin{array}{l}\text { Count of Open Charters within } \\
\text { Local School Zone }\end{array}$ \\
\hline Enrollment & $\begin{array}{l}-0.0001 \\
(0.0001)\end{array}$ & $\begin{array}{l}-0.0001 \\
(0.0003)\end{array}$ \\
\hline API Score & $\begin{array}{l}-0.0010 \\
(0.0007)\end{array}$ & $\begin{array}{c}0.0006 \\
(0.0006)\end{array}$ \\
\hline Percent Black & $\begin{array}{l}-0.0030 \\
(0.0036)\end{array}$ & $\begin{array}{l}0.0118 * * \\
(0.0053)\end{array}$ \\
\hline Percent Native American & $\begin{array}{c}0.0363 \\
(0.0346)\end{array}$ & $\begin{array}{l}-0.0004 \\
(0.0037)\end{array}$ \\
\hline Percent Asian & $\begin{array}{c}-0.0138 * * * \\
(0.0025)\end{array}$ & $\begin{array}{c}0.0041 \\
(0.0030)\end{array}$ \\
\hline Percent Filipino & $\begin{array}{l}-0.0204 * * \\
(0.0095)\end{array}$ & $\begin{array}{l}-0.0093 \\
(0.0069)\end{array}$ \\
\hline Percent Hispanic & $\begin{array}{c}-0.0092 * * * \\
(0.0027)\end{array}$ & $\begin{array}{c}0.0019 \\
(0.0027)\end{array}$ \\
\hline Percent Pacific Islander & $\begin{array}{l}-0.0340 * \\
(0.0201)\end{array}$ & $\begin{array}{l}-0.0167 \\
(0.0137)\end{array}$ \\
\hline Percent Gifted & $\begin{array}{c}0.0479 * * * \\
(0.0082)\end{array}$ & $\begin{array}{c}0.0031 \\
(0.0025)\end{array}$ \\
\hline Percent Free or Reduced Lunch & $\begin{array}{l}-0.0006 \\
(0.0020)\end{array}$ & $\begin{array}{l}0.0034^{*} \\
(0.0018)\end{array}$ \\
\hline Percent ELL & $\begin{array}{c}0.0068 * * * \\
(0.0024)\end{array}$ & $\begin{array}{l}-0.0007 \\
(0.0016)\end{array}$ \\
\hline Percent Disabled & $\begin{array}{l}0.0060 * \\
(0.0035)\end{array}$ & $\begin{array}{l}0.0052 * * \\
(0.0022)\end{array}$ \\
\hline Percent HS Graduate & $\begin{array}{l}-0.0043 \\
(0.0027)\end{array}$ & $\begin{array}{c}0.0001 \\
(0.0007)\end{array}$ \\
\hline Percent Bachelors Degree & $\begin{array}{l}-0.0015 \\
(0.0049)\end{array}$ & $\begin{array}{l}0.0022 * \\
(0.0012)\end{array}$ \\
\hline Percent Graduate School & $\begin{array}{c}-0.0034 \\
(0.0049)\end{array}$ & $\begin{array}{l}-0.0040 \\
(0.0034)\end{array}$ \\
\hline Observations & 5,858 & 5,858 \\
\hline R-squared & 0.126 & 0.974 \\
\hline School Fixed-Effects & $\mathrm{N}$ & $\mathrm{Y}$ \\
\hline Census Block Fixed-Effects & $\mathrm{N}$ & $\mathrm{N}$ \\
\hline
\end{tabular}

Notes: See Table 4 for a description of baseline sample. Robust standard errors clustered by elementary school zone in 2002 in parentheses. *, **, and *** denote significance at the $10 \%, 5 \%$ and $1 \%$ levels, respectively. 
Table A2: Heterogeneity by Neighborhood Income and Public School API using Charters in Home School District (Exculding LAUSD)

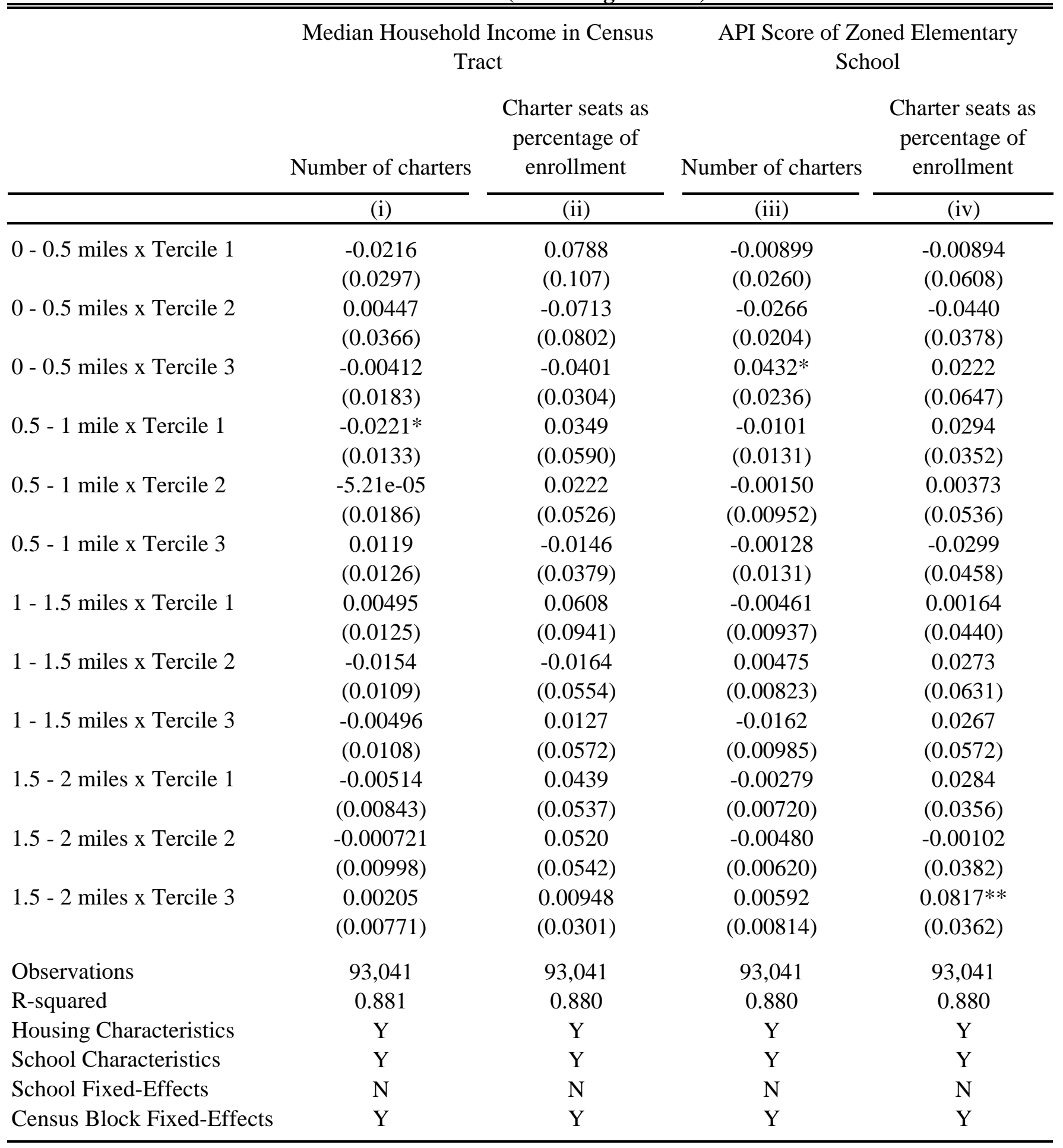

Notes: See Table 4 for a description of baseline sample. API scores are from the year of sale for the school that was zoned to the property in 2002. Robust standard errors clustered by elementary school zone in 2002 in parentheses. ${ }^{*}, * *$, and $* * *$ denote significance at the $10 \%, 5 \%$ and $1 \%$ levels, respectively. 
Table A3: Effect of Charters on Log Sale Prices by Charter Grade Levels

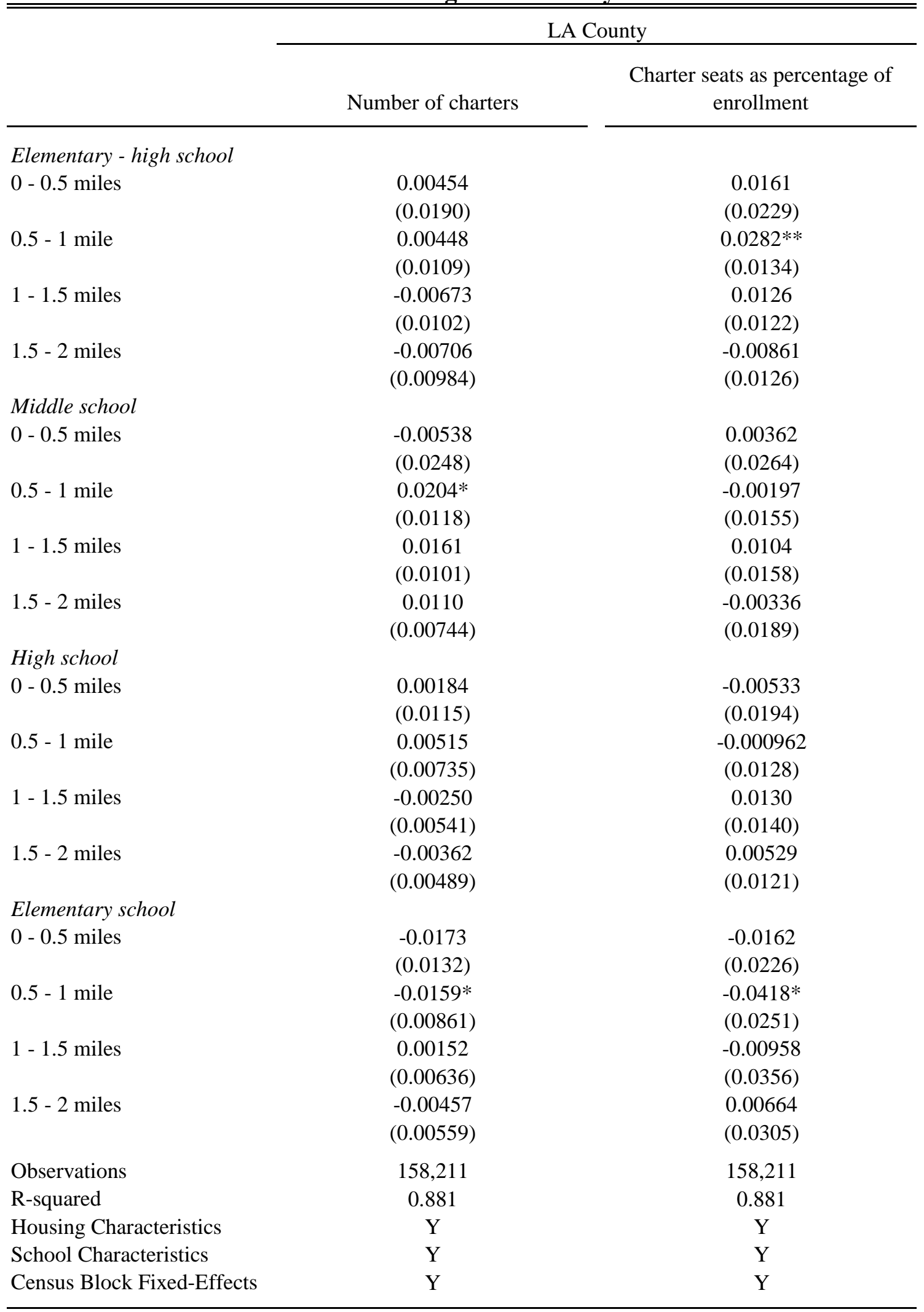

Notes: See Table 4 for a description of baseline sample and controls. Robust standard errors clustered by elementary school zone in 2002 in parentheses. *, **, and *** denote significance at the $10 \%, 5 \%$ and $1 \%$ levels, respectively. 


\begin{tabular}{|c|c|c|}
\hline & & Dunty \\
\hline & Number of charters & $\begin{array}{c}\text { Charter seats as percentage of } \\
\text { enrollment }\end{array}$ \\
\hline 0 - 0.5 miles x 2008 & -0.00164 & -0.00106 \\
\hline & $(0.0144)$ & $(0.0273)$ \\
\hline 0 - 0.5 miles x 2009 & -0.00305 & 0.00532 \\
\hline & $(0.00957)$ & $(0.0220)$ \\
\hline 0 - 0.5 miles x 2010 & -0.000975 & 0.0132 \\
\hline & $(0.00855)$ & $(0.0200)$ \\
\hline 0 - 0.5 miles x 2011 & -0.0106 & -0.0258 \\
\hline & $(0.00955)$ & $(0.0235)$ \\
\hline 0.5 - 1 mile x 2008 & 0.0102 & 0.00924 \\
\hline & $(0.00809)$ & $(0.0312)$ \\
\hline 0.5 - 1 mile x 2009 & -0.00327 & -0.0304 \\
\hline & $(0.00581)$ & $(0.0213)$ \\
\hline 0.5 - 1 mile x 2010 & 0.00127 & -0.0116 \\
\hline & $(0.00489)$ & $(0.0228)$ \\
\hline 0.5 - 1 mile x 2011 & 0.00244 & -0.00873 \\
\hline & $(0.00563)$ & $(0.0238)$ \\
\hline 1 - 1.5 miles x 2008 & $0.0141 * * *$ & 0.0135 \\
\hline & $(0.00472)$ & $(0.0324)$ \\
\hline 1 - 1.5 miles x 2009 & 0.00109 & -0.0318 \\
\hline & $(0.00372)$ & $(0.0272)$ \\
\hline 1 - 1.5 miles x 2010 & 0.00116 & -0.00301 \\
\hline & $(0.00318)$ & $(0.0307)$ \\
\hline 1 - 1.5 miles x 2011 & 0.00346 & -0.0109 \\
\hline & $(0.00350)$ & $(0.0313)$ \\
\hline 1.5 - 2 miles x 2008 & 0.00166 & 0.0461 \\
\hline & $(0.00474)$ & $(0.0394)$ \\
\hline 1.5 - 2 miles x 2009 & -0.00204 & -0.0137 \\
\hline & $(0.00354)$ & $(0.0294)$ \\
\hline 1.5 - 2 miles x 2010 & -0.000481 & -0.0141 \\
\hline & $(0.00322)$ & $(0.0312)$ \\
\hline 1.5 - 2 miles x 2011 & -0.000747 & 0.000509 \\
\hline & $(0.00305)$ & $(0.0299)$ \\
\hline Observations & 158,211 & 158,211 \\
\hline R-squared & 0.881 & 0.881 \\
\hline Housing Characteristics & $\mathrm{Y}$ & $\mathrm{Y}$ \\
\hline School Characteristics & $\mathrm{Y}$ & $\mathrm{Y}$ \\
\hline Census Block Fixed-Effects & $\mathrm{Y}$ & $\mathrm{Y}$ \\
\hline
\end{tabular}

Notes: See Table 4 for a description of baseline sample. Robust standard errors clustered by elementary school zone in 2002 in parentheses. ${ }^{*}, * *$, and $* * *$ denote significance at the $10 \%, 5 \%$ and $1 \%$ levels, respectively. 
Table A5: Heterogeneity by Neighborhood Income, Public School API, and Percent Minority

\begin{tabular}{|c|c|c|c|c|c|c|c|c|}
\hline & \multicolumn{8}{|c|}{ LA County } \\
\hline & \multicolumn{2}{|c|}{$\begin{array}{c}\text { Median Household Income in Census } \\
\text { Tract }\end{array}$} & \multicolumn{2}{|c|}{$\begin{array}{l}\text { API Score of Zoned Elementary } \\
\text { School }\end{array}$} & \multicolumn{2}{|c|}{ Percent Minority in Elementary School } & \multicolumn{2}{|c|}{ Percent Minority in Census Tract } \\
\hline & Number of charters & $\begin{array}{l}\text { Charter seats as } \\
\text { percentage of } \\
\text { enrollment }\end{array}$ & Number of charters & $\begin{array}{l}\text { Charter seats as } \\
\text { percentage of } \\
\text { enrollment }\end{array}$ & Number of charters & $\begin{array}{l}\text { Charter seats as } \\
\text { percentage of } \\
\text { enrollment }\end{array}$ & Number of charters & $\begin{array}{c}\text { Charter seats as } \\
\text { percentage of } \\
\text { enrollment }\end{array}$ \\
\hline & (i) & (ii) & (iii) & (iv) & (v) & (vi) & (vii) & (viii) \\
\hline 0 - 0.5 miles x Quartile 1 & $\begin{array}{l}0.011 \\
(0.014)\end{array}$ & $\begin{array}{c}0.079 \\
(0.053)\end{array}$ & $\begin{array}{c}0.001 \\
(0.012)\end{array}$ & $\begin{array}{l}-0.007 \\
(0.032)\end{array}$ & $\begin{array}{l}-0.026 \\
(0.040)\end{array}$ & $\begin{array}{l}-0.047 \\
(0.042)\end{array}$ & $\begin{array}{l}-0.032 \\
(0.050)\end{array}$ & $\begin{array}{l}-0.065 \\
(0.051)\end{array}$ \\
\hline 0 - 0.5 miles x Quartile 2 & $\begin{array}{c}-0.0530 * * * \\
(0.017)\end{array}$ & $\begin{array}{l}-0.068 \\
(0.056)\end{array}$ & $\begin{array}{l}-0.006 \\
(0.012)\end{array}$ & $\begin{array}{c}0.003 \\
(0.028)\end{array}$ & $\begin{array}{l}-0.001 \\
(0.019)\end{array}$ & $\begin{array}{c}0.027 \\
(0.039)\end{array}$ & $\begin{array}{l}-0.020 \\
(0.020)\end{array}$ & $\begin{array}{l}-0.055 \\
(0.036)\end{array}$ \\
\hline 0 - 0.5 miles x Quartile 3 & $\begin{array}{l}0.024 \\
(0.018)\end{array}$ & $\begin{array}{c}0.004 \\
(0.035)\end{array}$ & $\begin{array}{l}-0.015 \\
(0.017)\end{array}$ & $\begin{array}{l}-0.012 \\
(0.039)\end{array}$ & $\begin{array}{l}-0.001 \\
(0.012)\end{array}$ & $\begin{array}{c}0.022 \\
(0.031)\end{array}$ & $\begin{array}{l}-0.007 \\
(0.016)\end{array}$ & $\begin{array}{l}0.0812 * \\
(0.049)\end{array}$ \\
\hline 0 - 0.5 miles x Quartile 4 & $\begin{array}{l}-0.026 \\
(0.032)\end{array}$ & $\begin{array}{l}-0.052 \\
(0.042)\end{array}$ & $\begin{array}{l}0.017 \\
(0.026)\end{array}$ & $\begin{array}{c}0.000 \\
(0.042)\end{array}$ & $\begin{array}{l}-0.002 \\
(0.011)\end{array}$ & $\begin{array}{l}-0.005 \\
(0.032)\end{array}$ & $\begin{array}{c}0.004 \\
(0.012)\end{array}$ & $\begin{array}{l}0.019 \\
(0.034)\end{array}$ \\
\hline 0.5 - 1 mile x Quartile 1 & $\begin{array}{l}-0.002 \\
(0.008)\end{array}$ & $\begin{array}{c}0.039 \\
(0.049)\end{array}$ & $\begin{array}{l}-0.005 \\
(0.007)\end{array}$ & $\begin{array}{l}-0.006 \\
(0.034)\end{array}$ & $\begin{array}{c}0.003 \\
(0.014)\end{array}$ & $\begin{array}{c}0.001 \\
(0.037)\end{array}$ & $\begin{array}{c}0.013 \\
(0.024)\end{array}$ & $\begin{array}{l}-0.020 \\
(0.041)\end{array}$ \\
\hline 0.5 - 1 mile x Quartile 2 & $\begin{array}{c}0.000 \\
(0.010)\end{array}$ & $\begin{array}{c}0.029 \\
(0.048)\end{array}$ & $\begin{array}{l}-0.002 \\
(0.006)\end{array}$ & $\begin{array}{l}-0.027 \\
(0.036)\end{array}$ & $\begin{array}{l}-0.002 \\
(0.009)\end{array}$ & $\begin{array}{l}-0.027 \\
(0.027)\end{array}$ & $\begin{array}{l}-0.009 \\
(0.011)\end{array}$ & $\begin{array}{c}0.019 \\
(0.043)\end{array}$ \\
\hline 0.5 - 1 mile x Quartile 3 & $\begin{array}{l}-0.006 \\
(0.010)\end{array}$ & $\begin{array}{l}-0.069 \\
(0.071)\end{array}$ & $\begin{array}{c}0.008 \\
(0.007)\end{array}$ & $\begin{array}{c}0.028 \\
(0.044)\end{array}$ & $\begin{array}{l}-0.004 \\
(0.006)\end{array}$ & $\begin{array}{l}-0.033 \\
(0.041)\end{array}$ & $\begin{array}{l}-0.016 \\
(0.011)\end{array}$ & $\begin{array}{c}0.026 \\
(0.052)\end{array}$ \\
\hline 0.5 - 1 mile x Quartile 4 & $\begin{array}{c}0.007 \\
(0.012)\end{array}$ & $\begin{array}{l}-0.007 \\
(0.032)\end{array}$ & $\begin{array}{c}0.000 \\
(0.011)\end{array}$ & $\begin{array}{l}-0.017 \\
(0.033)\end{array}$ & $\begin{array}{c}0.000 \\
(0.006)\end{array}$ & $\begin{array}{c}0.034 \\
(0.048)\end{array}$ & $\begin{array}{c}0.002 \\
(0.007)\end{array}$ & $\begin{array}{l}-0.027 \\
(0.059)\end{array}$ \\
\hline 1 - 1.5 miles x Quartile 1 & $\begin{array}{c}0.005 \\
(0.005)\end{array}$ & $\begin{array}{c}0.021 \\
(0.073)\end{array}$ & $\begin{array}{c}0.005 \\
(0.004)\end{array}$ & $\begin{array}{l}-0.022 \\
(0.037)\end{array}$ & $\begin{array}{l}-0.008 \\
(0.010)\end{array}$ & $\begin{array}{l}-0.008 \\
(0.031)\end{array}$ & $\begin{array}{l}-0.012 \\
(0.014)\end{array}$ & $\begin{array}{l}-0.052 \\
(0.039)\end{array}$ \\
\hline 1 - 1.5 miles x Quartile 2 & $\begin{array}{c}0.0163^{* *} \\
(0.008)\end{array}$ & $\begin{array}{c}0.097 \\
(0.083)\end{array}$ & $\begin{array}{c}0.00790 * \\
(0.005)\end{array}$ & $\begin{array}{c}0.032 \\
(0.044)\end{array}$ & $\begin{array}{l}-0.005 \\
(0.007)\end{array}$ & $\begin{array}{l}-0.022 \\
(0.045)\end{array}$ & $\begin{array}{c}0.003 \\
(0.010)\end{array}$ & $\begin{array}{c}0.034 \\
(0.065)\end{array}$ \\
\hline 1 - 1.5 miles x Quartile 3 & $\begin{array}{l}-0.007 \\
(0.008)\end{array}$ & $\begin{array}{l}-0.049 \\
(0.046)\end{array}$ & $\begin{array}{c}0.001 \\
(0.006)\end{array}$ & $\begin{array}{c}0.006 \\
(0.035)\end{array}$ & $\begin{array}{c}0.008 \\
(0.006)\end{array}$ & $\begin{array}{l}-0.001 \\
(0.050)\end{array}$ & $\begin{array}{c}0.007 \\
(0.010)\end{array}$ & $\begin{array}{c}0.074 \\
(0.047)\end{array}$ \\
\hline 1 - 1.5 miles x Quartile 4 & $\begin{array}{l}-0.015 \\
(0.011)\end{array}$ & $\begin{array}{l}-0.012 \\
(0.038)\end{array}$ & $\begin{array}{l}-0.009 \\
(0.008)\end{array}$ & $\begin{array}{l}-0.016 \\
(0.038)\end{array}$ & $\begin{array}{c}0.00694 * \\
(0.004)\end{array}$ & $\begin{array}{c}0.043 \\
(0.056)\end{array}$ & $\begin{array}{c}0.005 \\
(0.004)\end{array}$ & $\begin{array}{c}0.008 \\
(0.066)\end{array}$ \\
\hline 1.5 - 2 miles x Quartile 1 & $\begin{array}{l}-0.002 \\
(0.004)\end{array}$ & $\begin{array}{l}-0.055 \\
(0.097)\end{array}$ & $\begin{array}{l}-0.002 \\
(0.003)\end{array}$ & $\begin{array}{c}0.021 \\
(0.039)\end{array}$ & $\begin{array}{c}0.002 \\
(0.009)\end{array}$ & $\begin{array}{l}-0.013 \\
(0.043)\end{array}$ & $\begin{array}{l}-0.005 \\
(0.013)\end{array}$ & $\begin{array}{l}-0.034 \\
(0.057)\end{array}$ \\
\hline 1.5 - 2 miles x Quartile 2 & $\begin{array}{l}-0.005 \\
(0.007)\end{array}$ & $\begin{array}{c}0.006 \\
(0.084)\end{array}$ & $\begin{array}{l}-0.003 \\
(0.005)\end{array}$ & $\begin{array}{l}-0.016 \\
(0.044)\end{array}$ & $\begin{array}{l}-0.003 \\
(0.007)\end{array}$ & $\begin{array}{l}-0.023 \\
(0.039)\end{array}$ & $\begin{array}{c}0.003 \\
(0.008)\end{array}$ & $\begin{array}{l}-0.009 \\
(0.049)\end{array}$ \\
\hline 1.5 - 2 miles x Quartile 3 & $\begin{array}{l}0.005 \\
(0.006)\end{array}$ & $\begin{array}{c}0.035 \\
(0.052)\end{array}$ & $\begin{array}{c}0.000 \\
(0.005)\end{array}$ & $\begin{array}{c}0.002 \\
(0.040)\end{array}$ & $\begin{array}{l}-0.004 \\
(0.004)\end{array}$ & $\begin{array}{c}0.002 \\
(0.056)\end{array}$ & $\begin{array}{l}-0.012 \\
(0.008)\end{array}$ & $\begin{array}{c}0.013 \\
(0.046)\end{array}$ \\
\hline 1.5 - 2 miles x Quartile 4 & $\begin{array}{l}-0.004 \\
(0.007)\end{array}$ & $\begin{array}{l}-0.026 \\
(0.042)\end{array}$ & $\begin{array}{l}-0.004 \\
(0.007)\end{array}$ & $\begin{array}{l}-0.030 \\
(0.055)\end{array}$ & $\begin{array}{l}-0.002 \\
(0.003)\end{array}$ & $\begin{array}{l}-0.007 \\
(0.070)\end{array}$ & $\begin{array}{c}0.000 \\
(0.003)\end{array}$ & $\begin{array}{c}0.062 \\
(0.070)\end{array}$ \\
\hline Observations & 158,211 & 158,211 & 158,211 & 158,211 & 158,211 & 158,211 & 158,211 & 158,211 \\
\hline R-squared & 0.85 & 0.85 & 0.85 & 0.85 & 0.85 & 0.85 & 0.85 & 0.85 \\
\hline Housing Characteristics & $\mathrm{Y}$ & $\mathrm{Y}$ & $\mathrm{Y}$ & $\mathrm{Y}$ & $\mathrm{Y}$ & $\mathrm{Y}$ & $\mathrm{Y}$ & $\mathrm{Y}$ \\
\hline School Characteristics & $\mathrm{Y}$ & $\mathrm{Y}$ & $\mathrm{Y}$ & $\mathrm{Y}$ & $\mathrm{Y}$ & Y & $\mathrm{Y}$ & $\mathrm{Y}$ \\
\hline School Fixed-Effects & $\mathrm{N}$ & $\mathrm{N}$ & $\mathrm{N}$ & $\mathrm{N}$ & $\mathrm{N}$ & $\mathrm{N}$ & $\mathrm{N}$ & $\mathrm{N}$ \\
\hline Census Block Fixed-Effects & Y & $\mathrm{Y}$ & $\mathrm{Y}$ & $\mathrm{Y}$ & $\mathrm{Y}$ & Y & $\mathrm{Y}$ & Y \\
\hline
\end{tabular}

Notes: See Table 4 for a description of baseline sample. API scores are from the year of sale for the school that

was zoned to the property in 2002. Robust standard errors clustered by elementary school zone in 2002 in

parentheses. *, **, and ${ }^{* * *}$ denote significance at the $10 \%, 5 \%$ and $1 \%$ levels, respectively. 
Table A6: Effect of Charters on Log Sale Prices - Specification Checks

\begin{tabular}{|c|c|c|c|c|c|c|c|c|c|}
\hline & $\begin{array}{l}\text { Use sale } \\
\text { levels }\end{array}$ & $\begin{array}{l}\text { Limit to 0-2 } \\
\text { Bedrooms }\end{array}$ & $\begin{array}{l}\text { Limit to 3+ } \\
\text { Bedrooms }\end{array}$ & $\begin{array}{c}\text { Include } \\
\text { Properties with } \\
>8 \text { Bedrooms }\end{array}$ & $\begin{array}{c}\text { Drop } \\
\text { Properties w/ } \\
>5000 \mathrm{sf}\end{array}$ & $\begin{array}{l}\text { Drop Multi- } \\
\text { Unit }\end{array}$ & $\begin{array}{l}\text { Summer } \\
\text { Only }\end{array}$ & $\begin{array}{l}\text { Add 2-5 } \\
\text { mile ring }\end{array}$ & $\begin{array}{c}\text { Include School } \\
\text { FE }\end{array}$ \\
\hline & (i) & (ii) & (iii) & (iv) & $(\mathrm{v})$ & (vi) & (vii) & (viii) & (ix) \\
\hline & \multicolumn{9}{|c|}{ A. Number of charters } \\
\hline 0 - 0.5 miles & $\begin{array}{l}-2181 \\
(2422)\end{array}$ & $\begin{array}{l}-0.0043 \\
(0.0147)\end{array}$ & $\begin{array}{l}-0.0019 \\
(0.0109)\end{array}$ & $\begin{array}{l}-0.0050 \\
(0.0087)\end{array}$ & $\begin{array}{l}-0.0061 \\
(0.0083)\end{array}$ & $\begin{array}{l}-0.0029 \\
(0.0087)\end{array}$ & $\begin{array}{c}0.0133 \\
(0.0262)\end{array}$ & $\begin{array}{l}-0.0068 \\
(0.0084)\end{array}$ & $\begin{array}{l}-0.0048 \\
(0.0083)\end{array}$ \\
\hline 0.5 - 1 mile & $\begin{array}{c}565 \\
(1383)\end{array}$ & $\begin{array}{c}0.0008 \\
(0.0075)\end{array}$ & $\begin{array}{c}0.0067 \\
(0.0061)\end{array}$ & $\begin{array}{c}0.0001 \\
(0.0049)\end{array}$ & $\begin{array}{c}0.0009 \\
(0.0048)\end{array}$ & $\begin{array}{l}-0.0016 \\
(0.0048)\end{array}$ & $\begin{array}{c}0.0074 \\
(0.0133)\end{array}$ & $\begin{array}{l}-0.0004 \\
(0.0049)\end{array}$ & $\begin{array}{c}0.0016 \\
(0.0048)\end{array}$ \\
\hline 1 - 1.5 miles & $\begin{array}{c}-272 \\
(921.8)\end{array}$ & $\begin{array}{c}0.0065 \\
(0.0056)\end{array}$ & $\begin{array}{l}-0.0026 \\
(0.004)\end{array}$ & $\begin{array}{c}0.0040 \\
(0.0034)\end{array}$ & $\begin{array}{c}0.0018 \\
(0.0031)\end{array}$ & $\begin{array}{c}0.0026 \\
(0.0034)\end{array}$ & $\begin{array}{c}0.0021 \\
(0.01020)\end{array}$ & $\begin{array}{c}0.0011 \\
(0.0032)\end{array}$ & $\begin{array}{c}0.0029 \\
(0.0031)\end{array}$ \\
\hline 1.5 - 2 miles & $\begin{array}{c}-5 \\
(875.6)\end{array}$ & $\begin{array}{c}0.0063 \\
(0.0059)\end{array}$ & $\begin{array}{l}-0.0050 \\
(0.0036)\end{array}$ & $\begin{array}{l}-0.0021 \\
(0.0032)\end{array}$ & $\begin{array}{l}-0.0013 \\
(0.0028)\end{array}$ & $\begin{array}{l}0.0011 \\
(0.003)\end{array}$ & $\begin{array}{l}-0.0048 \\
(0.0092)\end{array}$ & $\begin{array}{l}-0.0018 \\
(0.0029)\end{array}$ & $\begin{array}{l}-0.0007 \\
(0.0028)\end{array}$ \\
\hline \multirow[t]{2}{*}{2 - 5 miles } & & & & & & & & $\begin{array}{c}0.0009 \\
(0.0008)\end{array}$ & \\
\hline & \multicolumn{9}{|c|}{ B. Charter seats as percentage of enrollment } \\
\hline 0 - 0.5 miles & $\begin{array}{l}-3049 \\
(7929)\end{array}$ & $\begin{array}{c}0.007 \\
(0.037)\end{array}$ & $\begin{array}{c}0.006 \\
(0.025)\end{array}$ & $\begin{array}{c}0.001 \\
(0.023)\end{array}$ & $\begin{array}{c}-0.002 \\
(0.019)\end{array}$ & $\begin{array}{c}-0.005 \\
(0.021)\end{array}$ & $\begin{array}{l}0.053 \\
(0.06)\end{array}$ & $\begin{array}{c}-0.002 \\
(0.019)\end{array}$ & $\begin{array}{r}-0.002 \\
(0.02)\end{array}$ \\
\hline 0.5 - 1 mile & $\begin{array}{l}-2389 \\
(9215)\end{array}$ & $\begin{array}{c}0.022 \\
(0.048)\end{array}$ & $\begin{array}{c}-0.003 \\
(0.022)\end{array}$ & $\begin{array}{c}-0.009 \\
(0.021)\end{array}$ & $\begin{array}{c}-0.013 \\
(0.020)\end{array}$ & $\begin{array}{c}-0.019 \\
(0.020)\end{array}$ & $\begin{array}{c}0.047 \\
(0.057)\end{array}$ & $\begin{array}{c}-0.014 \\
(0.019)\end{array}$ & $\begin{array}{c}-0.012 \\
(0.020)\end{array}$ \\
\hline 1 - 1.5 miles & $\begin{array}{l}-4876 \\
(9456)\end{array}$ & $\begin{array}{c}0.039 \\
(0.049)\end{array}$ & $\begin{array}{c}-0.026 \\
(0.029)\end{array}$ & $\begin{array}{c}-0.004 \\
(0.025)\end{array}$ & $\begin{array}{l}-0.019 \\
(0.022)\end{array}$ & $\begin{array}{l}-0.010 \\
(0.024)\end{array}$ & $\begin{array}{c}0.034 \\
(0.058)\end{array}$ & $\begin{array}{c}-0.013 \\
(0.024)\end{array}$ & $\begin{array}{c}-0.013 \\
(0.024)\end{array}$ \\
\hline 1.5 - 2 miles & $\begin{array}{c}3330 \\
(9264)\end{array}$ & $\begin{array}{c}0.028 \\
(0.066)\end{array}$ & $\begin{array}{c}0.001 \\
(0.027)\end{array}$ & $\begin{array}{c}-0.013 \\
(0.03)\end{array}$ & $\begin{array}{c}-0.009 \\
(0.026)\end{array}$ & $\begin{array}{c}0.002 \\
(0.026)\end{array}$ & $\begin{array}{c}-0.001 \\
(0.040)\end{array}$ & $\begin{array}{c}-0.003 \\
(0.026)\end{array}$ & $\begin{array}{c}-0.006 \\
(0.026)\end{array}$ \\
\hline 2 - 5 miles & & & & & & & & $\begin{array}{c}0.096 \\
(0.082)\end{array}$ & \\
\hline Observations & 158,211 & 49,432 & 108,779 & 159,906 & 157,783 & 151,797 & 42,962 & 158,211 & 158,211 \\
\hline R-squared & 0.90 & 0.89 & 0.91 & 0.87 & 0.88 & 0.89 & 0.93 & 0.88 & 0.88 \\
\hline
\end{tabular}

Note: The data cover sales from September 2008 through September 2011. All regressions control for the following: month by year fixed effects; census block fixed effects; housing characteristic controls - number of bedrooms, bathrooms, square footage, and quality; school characteristics - API levels overall, lags and second lags of overall API scores, \% of students of each race, \% free lunch, \% gifted, \% English language learners, \% disabled, and parent education levels. Standard errors clustered at the school level are in parentheses. ${ }^{* * *},{ }^{* *}$, and $*$ indicate significance at the $1 \%, 5 \%$, and $10 \%$ levels, respectively. 
Table A7 - Effect of Charters on Log Sale Prices for Los Angeles County - All Controls Shown

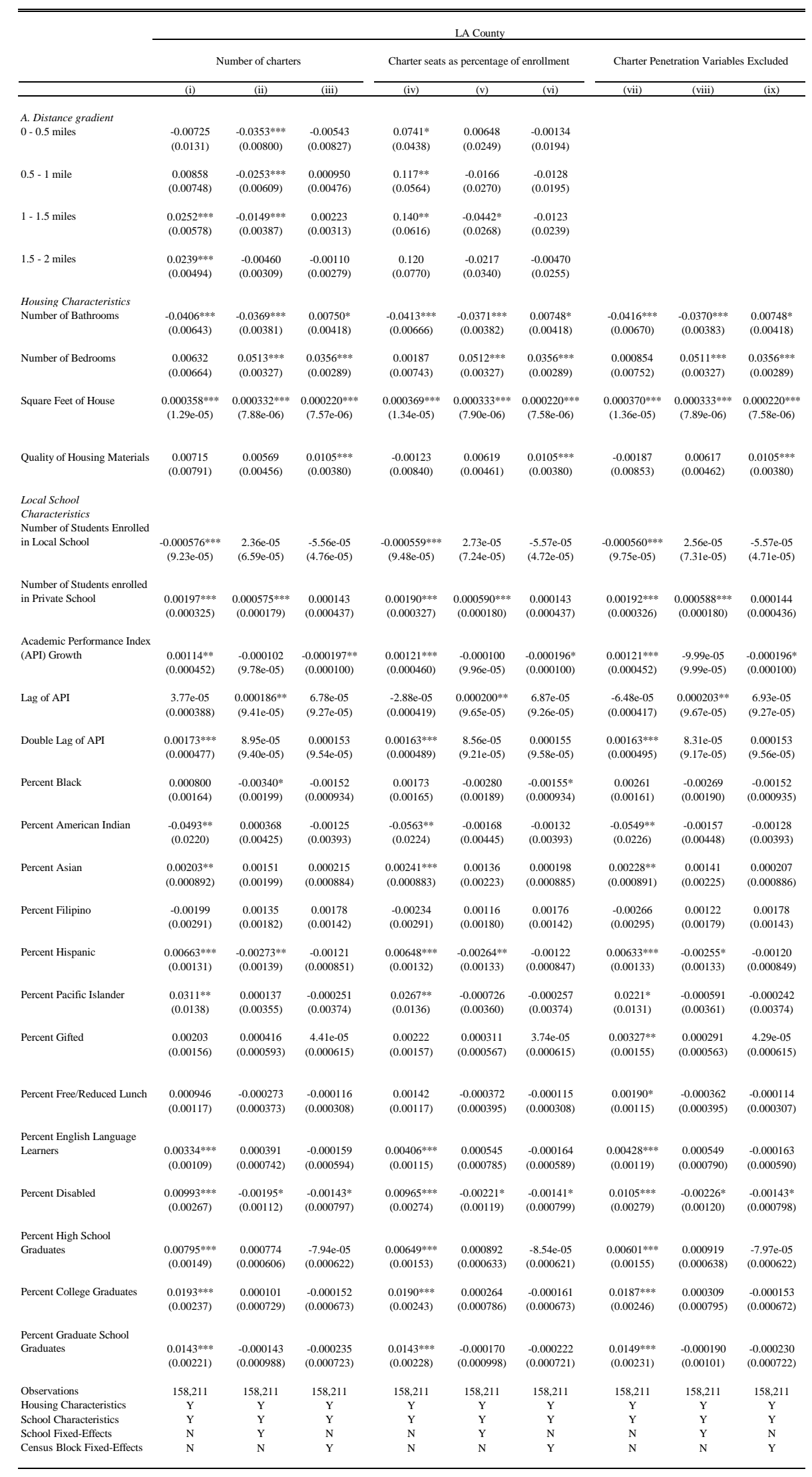

Sample includes property sales from April 2009 through September, 2011. The independent variable denotes either the number of charters in operation or the share of enrollment in operating charters as of the sale date in various distance rings from the property. Housing chracteristics include number of bedrooms, bathrooms, square footage, and quality. School chracteristics include API levels overall, lags and second lags of overall API scores, \% of students of each race, \% free lunch, \% gifted, \% English language learners, \% disabled, and parent education levels for elementary school zoned to the property in 2002. All regressions include month-by-year fixed-effects. Robust standard errors clustered by elementary school zone in 2002 in parentheses. *,**, and *** denote significance at the $10 \%, 5 \%$ and $1 \%$ levels, respectively. 